\title{
Analysis and design of emergency field isolation hospital building using innovative rapidly construction prefabricated units to treat patients infected with COVID-19
}

\author{
Abdul Qadir Bhatti ${ }^{1,2}$ (Abdul Wahab ${ }^{1}$ \\ Received: 23 November 2020 / Accepted: 27 December 2020 / Published online: 1 February 2021 \\ (c) Springer Nature Switzerland AG 2021
}

\begin{abstract}
Coronavirus pandemic is the most catastrophic phenomena of nature. In a major disaster which affected substantially to human lifecycle and property loss. Instant rehabilitation for the people affected with coronavirus was essential. As an immediate measure, it led to the application of light-gauge steel within Saudi Arabia for quick construction, in addition for the safety purposes during disaster in the forthcoming. Several hospital buildings with changeable categories of earthquake and seismic performance design needs are present. Broadly, the earthquake performance is categorized into two types: structural and non-structural, either under unsatisfactory conditions can be dangerous to occupants in the building once damage occurs. The deprivation in structural support of hospital building's systems (i.e. lateral and vertical force resisting systems) like frames and walls in the hospital building comes under structural damage, whereas the non-structural damage means the damage which doesn't affect the structural support system reliability such as pipes damage and pumps disruption, window breaking, breakdown of chimney viz. Furthermore, the non-structural damage is life intimidating also uneconomical.
\end{abstract}

Keywords Prefabricated structures $\cdot$ Structural analysis $\cdot$ Light-gauge steel structures

\section{Introduction}

Several building types with seismic design requirements and changing performance are present. The earthquake performance in buildings is broadly divided in two types structural and non-structural, either under unsatisfactory conditions can be dangerous to occupiers of the building while the damage occurs. The structural damage refers to the building deprivation with structural support methods (lateral force and vertical resisting methods) like building walls, frames, etc, whereas the non-structural damage means any damage without effecting the uniformity of support system such as the failure of chimney, windows breaking, any destruction of pipes, disturbance of pumps and telecommunication

Abdul Qadir Bhatti

draqbhatti@iu.edu.sa; draqbhatti@gmail.com;

abdul.bhatti@fulbrightmail.org

1 Department of Civil Engineering, Faculty

of Engineering, Islamic University of Madinah, Madinah,

Kingdom of Saudi Arabia

2 School of Civil Engineering, Universiti Teknologi Malaysia, 81310 Johor, Malaysia equipment destruction. [1, 2]. The non-structural damage is life intimidating also uneconomical. The expected form of damage is a difficult concern, which is influenced by the structure configuration, type and age, materials used for the construction, conditions on site, building proximity to neighbouring buildings and the form of non-structural elements $[3,4]$.

The use of reinforcement is not novel. The outer straps of iron were usually used in stonework. In 1825, the reinforced brickwork was used initially. The masonry providing with reinforced concrete elements in both the ways horizontal and vertical is called as "Confined Masonry". The masonry structures achieve stability with support of elements like cross walls, floors, roofs. When the load distribution is uniform, the load bearing walls are more efficient, whereas the eccentric loading is eluded with sufficient strength provision to walls, floors, also by giving satisfactory slab stiffness, support fixity. It must be considered throughout the planning stage of masonry structures $[5,6]$.

The use of steel buildings with light-gauge for agricultural structures, manufacturing works, storerooms and official buildings are common. With a storey height between 1 and 2. The prefab members application has improved the 
height of the building till six storey. The manufacturing of frames using steel having shorter length measurement of the building with repelling lateral forces in form of moment frames are typical, whereas the forces in longer direction are typically counterattacked with the diagonal steel rod bracing. As buildings of such type are lightweight, low rise, also built of steel members generally carry out fine during earthquakes with low collapses. In 2005, the earthquake in Kashmir with a magnitude of 7.6 on Richter scale on the Himalayan western boundary. As an estimate around 780,000 buildings were destroyed or damaged and are reduced to unusable for a long period. Roughly, 17,000 institutional buildings also major hospitals close by epicentre were damaged severely. The aim of this research is to come up with a cost-effective type building with smaller amount of viability to earthquake destructions $[7,8]$.

This research commenced using the literature available on light-gauge steel or cold-formed steel. Then, the selection of typical hospital building plans was done. Later, the building plan for the particular hospital was designed. A three-storied hospital building was designed by STAAD Pro programme as a light-gauge steel structure confirming the seismic provisions for reinforced masonry of Saudi Building Code.

\section{Cold Form Steel}

In England, the first sheet rolling mills were introduced by Henry Cort in 1784 and directed the structural application for first cold-formed steel and industrialized in America well ahead in 1923 by John Tytus further headed to the current manufacturing on strip coiled steel basis. Also, the corrugated steel sheets with light-gauge for building sheathing. The Fig. 1 depicts the cold form steel building $[9,10]$.

\section{The principles of design for the light-gauge steel sections}

The American Iron and Steel Institute (AISI) initiated conducting research since 1939 which is currently supervised by structural professionals allied by the AISI commissions for the strip and sheet steel manufacturers. The requirement was reviewed and amended frequently from initial publication in 1946 is implemented [11-13].

Design basis at present, the allowable strength design method (ASD) structural design of light-guage members is briefed and applied. The Fig. 2 illustrates the cold-formed steel framing used for housing [14-16]. The required strengths in allowable strength design method are axial loads, bending moments and shear force, etc., for structural members and are calculated with analysis of structures for working loads. The necessary strength shall not go beyond design strength allowable limit and is given below:

$R \leq \frac{R_{\mathrm{n}}}{\Omega}$

where $R_{n}=$ nominal strength specified in the AISI specification. $\Omega=$ safety factor specified in the AISI specification. $R=$ required strength. $\frac{R_{\mathrm{n}}}{\Omega}=$ allowable design strength.

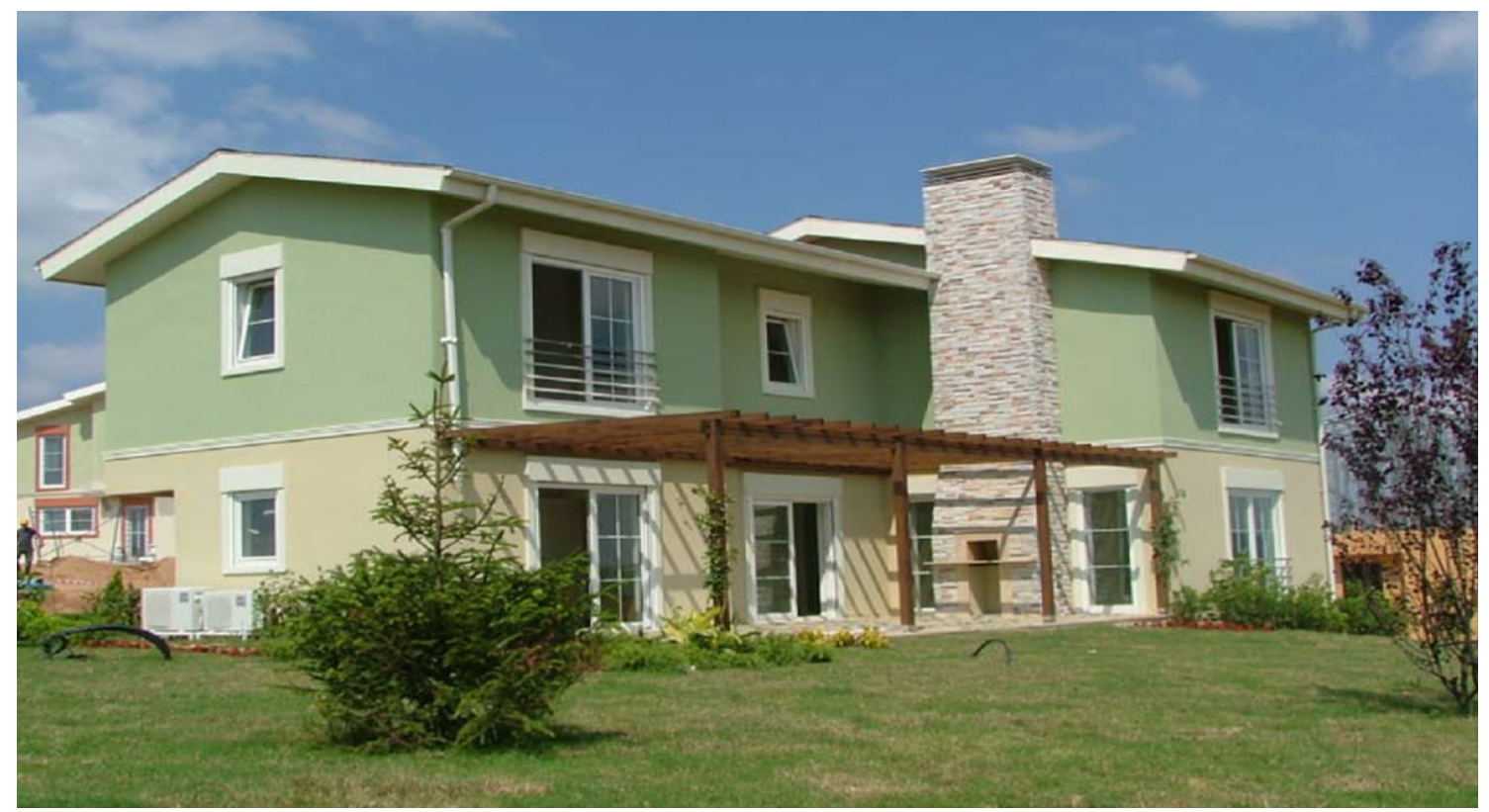

Fig. 1 Cold form steel building 
Fig. 2 Structural design of prefabricated cold formed steel for house construction
Table 1 Metric sheeting physical properties

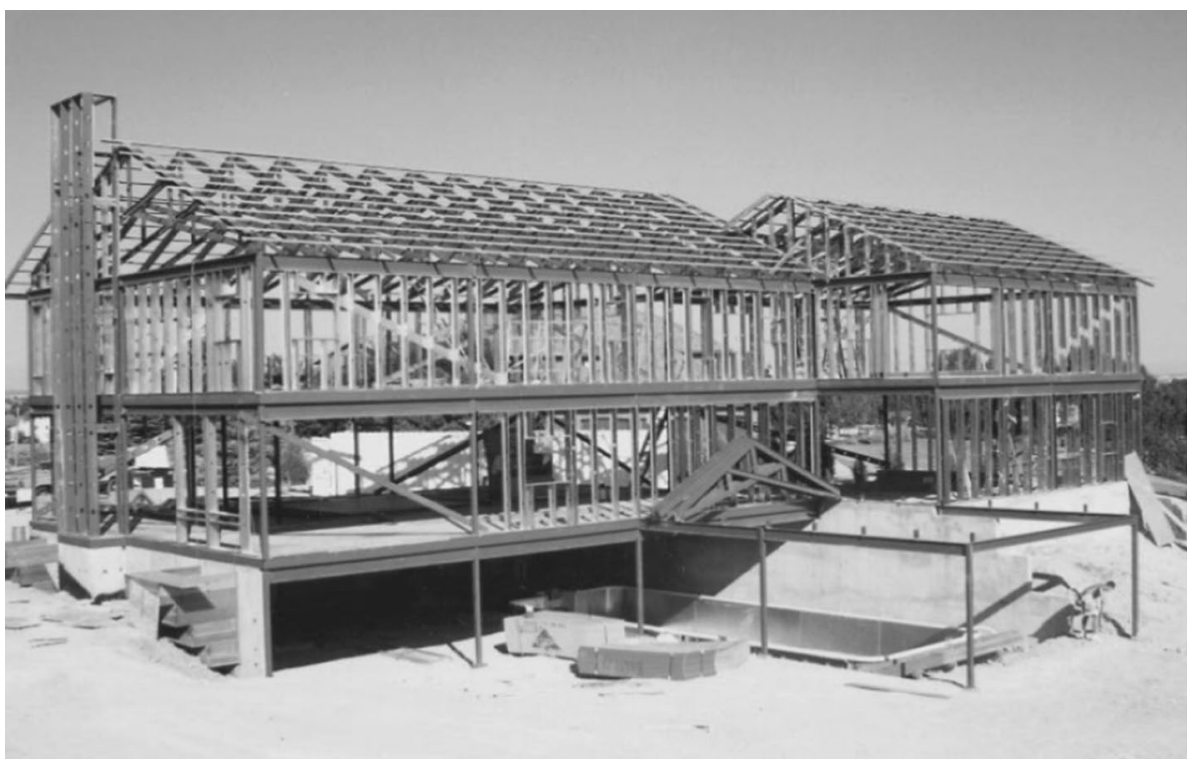

\begin{tabular}{|c|c|c|c|c|c|c|c|}
\hline \multirow[t]{3}{*}{ Gauge } & \multirow[t]{3}{*}{$\begin{array}{l}\text { Uncoated } \\
\text { thickness }\end{array}$} & \multicolumn{2}{|l|}{ Weight } & \multirow{2}{*}{\multicolumn{2}{|c|}{$\begin{array}{l}\text { Section properties } \\
\overline{\text { Sections modulus, } \text { in }^{3}}\end{array}$}} & \multirow{2}{*}{\multicolumn{2}{|c|}{$\begin{array}{l}\begin{array}{l}\text { Moment of inertia, } \\
\text { in }^{4}\end{array} \\
\begin{array}{l}\text { Moment of inhertia, } \\
\text { in }^{4}\end{array}\end{array}$}} \\
\hline & & \multirow[t]{2}{*}{ lbs/ft of pile } & \multirow[t]{2}{*}{$\mathrm{lbs} / \mathrm{ft}^{2}$ of wall } & & & & \\
\hline & & & & Per section & Per ft & Per section & Per $\mathrm{ft}$ \\
\hline 5 & 0.209 & 19.1 & 11.6 & 5.50 & 3.36 & 9.40 & 5.73 \\
\hline 7 & 0.179 & 16.4 & 10.0 & 4.71 & 2.87 & 8.00 & 4.88 \\
\hline 8 & 0.164 & 15.2 & 9.3 & 4.35 & 2.65 & 7.36 & 4.49 \\
\hline 10 & 0.134 & 12.5 & 7.6 & 3.60 & 2.20 & 6.01 & 3.67 \\
\hline 12 & 0.105 & 9.9 & 6.0 & 2.80 & 1.71 & 4.68 & 2.85 \\
\hline
\end{tabular}

Based on AISI "Handbook of steel drainage and highway construction products," 1994
Generally, for design of buildings, the loading criteria are taken into account in such a way that the buildings are identified to meet the combinations of dead load, live load, snow load, and wind load confirming the requirements of a number of model building codes, also geographical requirements of location. The above standard methods of load application and maximum loadings, to use where load requirements are not established by local building codes [17-19]
Table 2 Metric sheeting physical properties

\begin{tabular}{|c|c|c|c|c|c|}
\hline \multirow[t]{2}{*}{ Gauge } & \multirow{2}{*}{$\begin{array}{l}\text { Uncoated } \\
\text { thickness, in }\end{array}$} & \multicolumn{2}{|c|}{ Weight } & \multirow{2}{*}{$\begin{array}{l}\text { Section } \\
\text { modulus, } \\
\mathrm{in}^{3} / \mathrm{ft}\end{array}$} & \multirow{2}{*}{$\begin{array}{l}\text { Moment of } \\
\text { inertia in } 4 / \mathrm{f}\end{array}$} \\
\hline & & $\mathrm{lbs} / \mathrm{ft}$ & $\mathrm{lbs} / \mathrm{ft}^{2}$ & & \\
\hline 7 & 0.179 & 13.86 & 9.24 & 2.37 & 3.56 \\
\hline 8 & 0.164 & 12.70 & 8047 & 2.13 & 3.20 \\
\hline 10 & 0.134 & 10.37 & 6.91 & 1.84 & 2.74 \\
\hline
\end{tabular}

Based on AISI "Handbook of steel drainage and construction products," 1994 


\section{Steel lightweight sheeting}

In general, to support the earth pressure on walls of excavations and trenches, the corrugated sheeting is used as beam strength, in addition the column strength for driving. Further, for driving easily, a small end cross section is provided with sheeting [20-23]. The sheeting physical properties are shown in Tables 1 and 2. [24-26].

\section{Modelling, analysis and design criteria}

\section{Description of three storey hospital building model}

This research portrays the design of earthquake resistant structure using cold formed steel. The structure taken for

Table 3 General characteristics of hospital building

\begin{tabular}{ll}
\hline Type of building & Hospital building \\
\hline Number of storeys & $\mathrm{G}+2$ \\
Area of the building & $5400 \mathrm{Sq} . \mathrm{ft}$ \\
Height of building & $44.5 \mathrm{ft}$ \\
Ceiling beight & $11 \mathrm{ft}$ \\
Height of truss & $8.5 \mathrm{ft}$ \\
Sill level & $3 \mathrm{ft}$ \\
Lintel level & $7 \mathrm{ft}$ \\
\hline
\end{tabular}

this thesis is three storey hospital building ground, first and second floor as shown in Fig. 4, 5 and 6, which comes under zone $2 \mathrm{~A}$ according to building code of Saudi Arabia. Moreover, the structure is also designed for wind loads keeping in view the climatic conditions of the city. The general characteristics of building hospital are mentioned in Table 3.

Architectural drawings of hospital are shown in Fig. 3, 4 and 5.

\section{Loading data}

Dead load calculation for three storey hospital building is shown Table 4. Self-weight of sheet comes under dead load for roof. The $24 \mathrm{~mm}$ fibreboard with cement, floor finishes with $10 \mathrm{~mm}$ screed dead load comprised of first and second floor self-weight was used. Live load calculation for hospital building is shown in Table 5 and 6. Live loads for hospitals are taken from ASCE 7-05. ASCE classifies the hospital as IV and provides with the least live loads. Wind load calculation as shown in Table 7 is generated automatically for the hospital building providing the following details based on;
Fig. 3 Ground floor plan of hospital

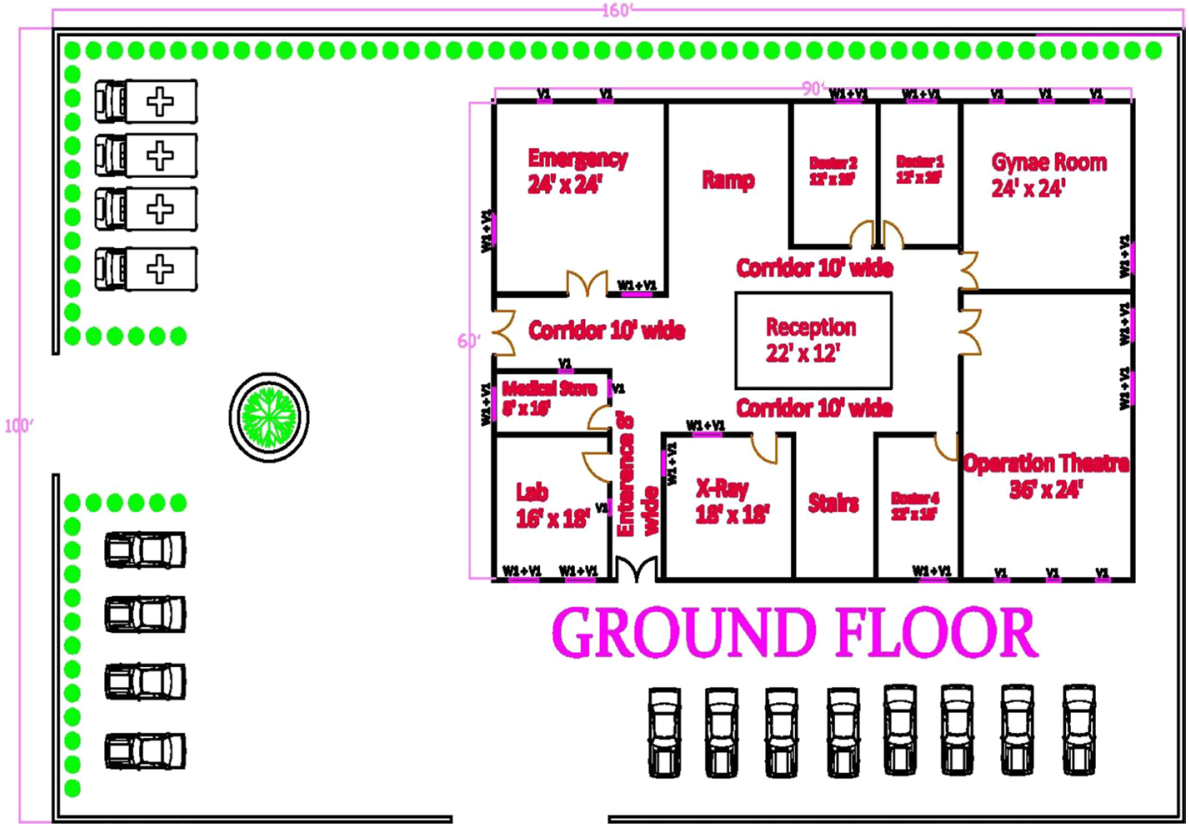


Fig. 4 First floor plan of hospital

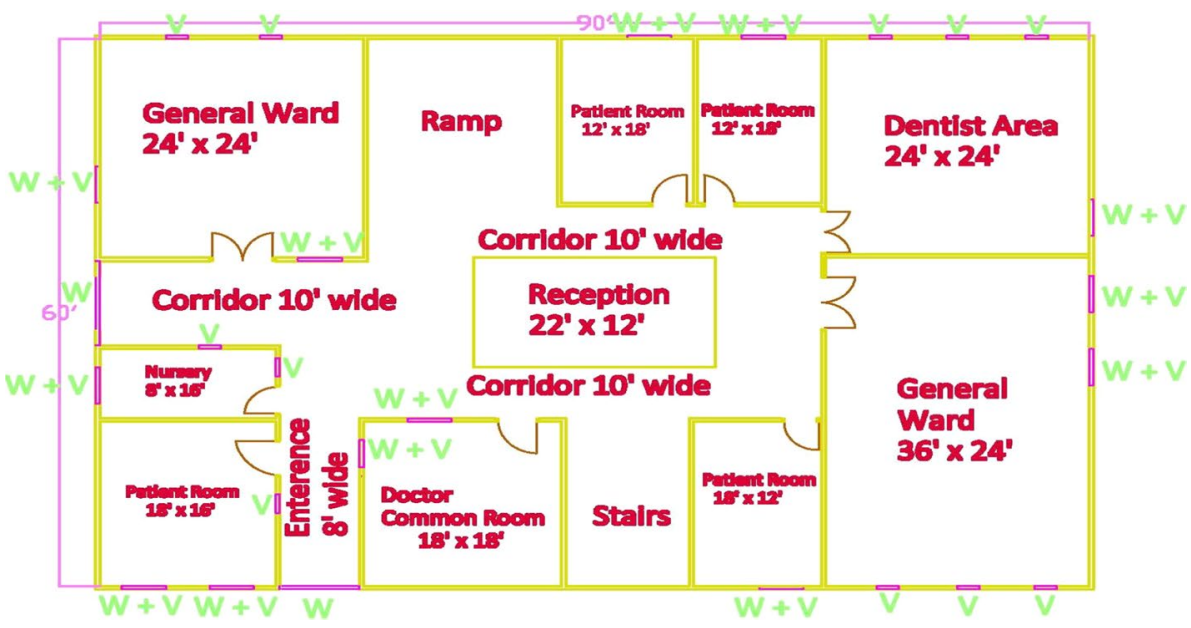

Fig. 5 Second floor plan of hospital

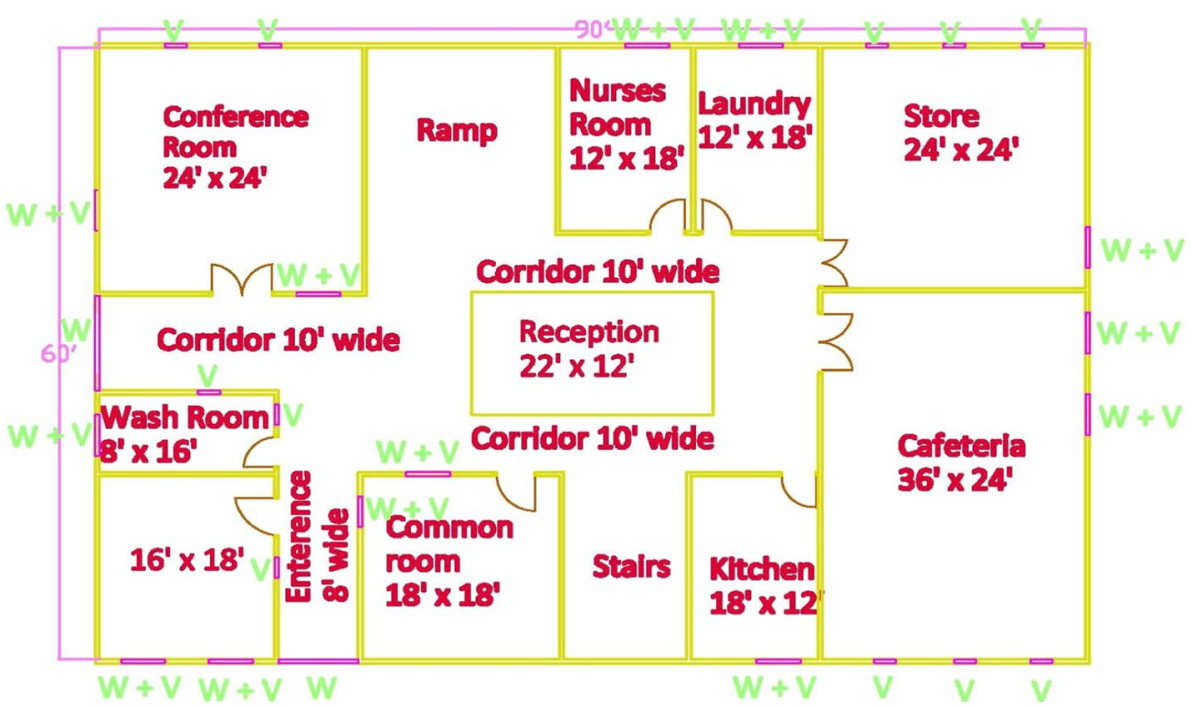

\begin{tabular}{ll}
\hline Code & ASCE-7-02 \\
\hline Building classification & Category IV \\
Basic wind speed & $100 \mathrm{mph}$ \\
Exposure category & Exposure C \\
Structure type & Building structure \\
\hline
\end{tabular}

Seismic loads are calculated based on UBC as shown in Table 8. All other loads are calculated manually using ASCE-7-02, UBC-97 and MBMA.

\section{Description of the section}

Stud distances are established subsequently after calculating the moments and vertical loads for which two feet distance was decent enough for the sheet strength and vertical load. With the additional diagonal strut, the bracing was adequate. Truss spacing is considered with wind load, DL and LL reversal of wind load. The suitable spacing was found as four feet and also decent for the sheets. The anchorage bolts are broadly accepted for the system expansion of bolts for which Hilt and Rawal bolts are used in general for applied strength requirement. The carbon steel which is compliant to ASTM C1513-04 with a diameter of $4.8 \mathrm{~mm}$ and self-drilling screw hex head was used. C-lipped section CS3 $75 \times 090$ is applied for all members. The Fig. 6 shows the sectional properties of C-lipped section having web (16 in), flange (3.75 in), lip(0.50 in) and thickness (0.09 in). 
Table 4 Dead load calculation for hospital building

\begin{tabular}{|c|c|c|}
\hline Load type & Value & Units \\
\hline \multicolumn{3}{|c|}{ (a) Dead load $=$ Self-weight + superimposed dead load } \\
\hline \multicolumn{3}{|c|}{ (1) Roof sheet } \\
\hline $0.7 \mathrm{~mm}$ thick GI sheet & 1.126 & psf \\
\hline \multicolumn{3}{|l|}{ (2) False ceiling } \\
\hline \multicolumn{3}{|l|}{ Hat section } \\
\hline Thickness & 0.2 & $\mathrm{~mm}$ \\
\hline Girth & 72 & $\mathrm{~mm}$ \\
\hline \multirow[t]{2}{*}{ Weight } & 0.2 & $\mathrm{~kg} / \mathrm{sq} . \mathrm{ft}$ \\
\hline & 0.441 & psf \\
\hline \multicolumn{3}{|l|}{ Cement board } \\
\hline Thickness & 4.5 & $\mathrm{~mm}$ \\
\hline Density & 1390 & $\mathrm{~kg} / \mathrm{m}^{\wedge} 3$ \\
\hline Pressure & 6.255 & $\mathrm{~kg} / \mathrm{m}^{\wedge} 2$ \\
\hline Pressure(load) & 1.282000576 & psf \\
\hline Total pressure(load of false ceiling) & 1.723 & psf \\
\hline \multicolumn{3}{|l|}{ (3) Wall cladding and insulation } \\
\hline \multicolumn{3}{|l|}{ Insulation } \\
\hline Thickness & 50 & $\mathrm{~mm}$ \\
\hline Density & 10 & $\mathrm{~kg} / \mathrm{m}^{\wedge} 3$ \\
\hline Pressure & 0.5 & $\mathrm{~kg} / \mathrm{m}^{\wedge} 2$ \\
\hline Pressure(load) & 0.102478064 & psf \\
\hline \multicolumn{3}{|l|}{ Internal cladding } \\
\hline Thickness & 10 & $\mathrm{~mm}$ \\
\hline Density & 1390 & $\mathrm{~kg} / \mathrm{m}^{\wedge} 3$ \\
\hline Pressure & 13.9 & $\mathrm{~kg} / \mathrm{m}^{\wedge} 2$ \\
\hline Pressure(Load) & 2.84889017 & psf \\
\hline \multicolumn{3}{|l|}{ External cladding } \\
\hline Thickness & 12 & $\mathrm{~mm}$ \\
\hline Density & 1390 & $\mathrm{~kg} / \mathrm{m}^{\wedge} 3$ \\
\hline Pressure & 16.68 & $\mathrm{~kg} / \mathrm{m}^{\wedge} 2$ \\
\hline Pressure (load) & 3.418668203 & psf \\
\hline Total pressure (load of cladding) & 6.370 & psf \\
\hline UDL on each stud & 12.74007287 & $\mathrm{lbs} / \mathrm{ft}$ \\
\hline
\end{tabular}

Calculation of dead load at different levels:

Dead load at roof level (36ft)

(1)self-weight of truss member

(2)Roof sheet

$1.12623392 \quad$ psf

(3) False ceiling

1.723000576

psf

Total DL

2.849

psf

Dead load at 2nd floor level (24ft)

(1) $20 \mathrm{~mm}$ ceramic tile

9.427981856

psf

(2) $10 \mathrm{~mm}$ screed

(3) $24 \mathrm{~mm}$ cement fibreboard

7.911306514

psf

$5.697780339 \quad$ psf

1.723000576 psf

$24.760 \quad$ psf

Total DL

Nodal load for joist

$99.04027714 \quad$ lbs

Dead load at $1^{\text {st }}$ floor level $(12 \mathrm{ft})$

(1) $20 \mathrm{~mm}$ ceramic tile
(2) $10 \mathrm{~mm}$ screed
(3) $24 \mathrm{~mm}$ cement fibreboard
(4) False ceiling

$9.427981856 \quad$ psf

$7.911306514 \quad$ psf

$5.697780339 \quad$ psf

$1.723000576 \quad$ psf 
Table 4 (continued)

\begin{tabular}{lll}
\hline Load type & Value & Units \\
\hline Total dead load & 24.760 & psf \\
Nodal load for joist & 99.04027714 & lbs \\
\hline
\end{tabular}

Table 5 Live load for hospital building

\begin{tabular}{lll}
\hline Occupancy or use & Value & Unit \\
\hline Operating rooms & 60 & $\mathrm{psf}$ \\
Operating rooms(nodal load) & 240 & $\mathrm{lbs}$ \\
Private rooms & 40 & $\mathrm{psf}$ \\
Private rooms (nodal load) & 160 & $\mathrm{lbs}$ \\
Wards & 40 & $\mathrm{psf}$ \\
Wards(nodal load) & 160 & $\mathrm{lbs}$ \\
Corridors (2nd floor) & 80 & $\mathrm{psf}$ \\
Corridors (2nd floor) nodal load & 320 & $\mathrm{lbs}$ \\
Corridors (1st floor) & 100 & $\mathrm{psf}$ \\
Corridors (1st floor) nodal load & 400 & $\mathrm{lbs}$ \\
Stores & 100 & $\mathrm{psf}$ \\
Stores (nodal load) & 400 & $\mathrm{lbs}$ \\
\hline
\end{tabular}

Table 6 Live roof load of hospital building

\begin{tabular}{ll}
\hline $\begin{array}{l}\text { Code: ASCE-07(Sect. 4.9, } \\
\text { page \#11) }\end{array}$ \\
\hline$L_{\mathrm{r}}=20 R_{1} R_{2}$ & \\
$R_{1}$ & 0.6 \\
$R_{2}$ & 1 \\
$L_{\mathrm{r}}$ & 12 \\
\hline
\end{tabular}

\section{Material}

G-350 material having yield strength of $50 \mathrm{ksi}$ with G-90 coating is used. $1.15 \mathrm{~mm}$ thickness is used for ground floor, and 0.09 thick is used for first floor. Deflection should be within the following limits vertical deflection should not exceed L/360, where $\mathrm{L}$ is the effective span of the member under consideration and while members are loaded with live load as well as dead load the deflection should not exceed the maximum allowable deflection of L/240. Horizontal deflection/sway.

1. The horizontal deflection for wall panels shall not exceed L/120.

2. The horizontal deflection for main structural frame shall not exceed $\mathrm{H} / 100$.

\section{Modelling of three storey hospital building}

STAAD PRO is used for modelling and analysis of cold form steel building hospital. The principle of matrix stiffness is used in this programme. For assignment of structure elements, the STAAD PRO built-up library of the cold formed standards section has been used. After the structure has been modelled, the restraints have to be given. In case of steel structures, a pin supports are given. The Figs. 7, 8, 9 and 10 show the different views of structural model of hospital.

\section{Analysis and design results}

\section{Time history analysis of structure}

This is the last step in the analysing of a structure using STAAD. PRO. When the run analysis is executed it shows analysis complete which indicates the termination of analysis process. The Fig. 11 depicts the stress contours of corner stud of ground floor, Fig. 12 Fx graph of corner stud of ground floor and Fig. 12 Fy graph of corner stud of ground floor and Fig. $12 \mathrm{Mz}$ graph of corner stud of ground floor. Furthermore, the Fig. 15 stress contours of member of bracing over window, Fig. 16 Fx graph of member of bracing over window, Fig. 17 Fy graph of member of bracing over window and Fig. $18 \mathrm{Mz}$ graph of member of bracing over window.

Similarly, different components stress and Fx, Fy and Mz graph of member are shown in Fig. 19, 20, 21, 22, 23, 24, 25 and 26, respectively. The graphical results of analysis are shown in the following figures from Figs. 11, 12, 13, 14, 15, $16,17,18,19,20,21,22,23,24,25$ and 26.

\section{Stress contour of beam}

\section{Mode shapes}

With increase in the number of degrees of freedom of structure, it rapidly turn out to be challenging to evaluate the time 
Table 7 Wind load for hospital building

\begin{tabular}{|c|c|c|c|c|c|c|}
\hline \multicolumn{4}{|c|}{ Building classification category } & \multicolumn{3}{|l|}{1} \\
\hline \multicolumn{4}{|c|}{ Basic wind speed(V) } & \multicolumn{3}{|l|}{100} \\
\hline \multicolumn{4}{|c|}{ Exposure category } & \multicolumn{3}{|l|}{$\mathrm{C}$} \\
\hline \multicolumn{4}{|c|}{ Enclosure classification } & \multicolumn{3}{|l|}{ Enclosed building } \\
\hline \multicolumn{4}{|c|}{ Code } & \multicolumn{3}{|l|}{ ASCE-07 } \\
\hline \multicolumn{7}{|c|}{$q_{\mathrm{h}}=0.0256 * k_{\mathrm{z}} * k_{\mathrm{zt}} * k_{\mathrm{d}} *\left(V^{2}\right) * \mathrm{I}$} \\
\hline \multicolumn{4}{|c|}{$k_{\mathrm{z}}($ Velocity pressure exposure coefficient $)$} & 1.04 & \multicolumn{2}{|l|}{ Table 6-3 } \\
\hline \multicolumn{4}{|c|}{$k_{\mathrm{zt}}($ Topographic factor $)$} & 1 & \multicolumn{2}{|l|}{$\mathrm{k}_{\mathrm{zt}}=\left(1+\mathrm{k}_{1} \mathrm{k}_{2} \mathrm{k}_{3}\right)^{2}$} \\
\hline \multicolumn{4}{|c|}{$k_{\mathrm{d}}$} & 0.85 & \multicolumn{2}{|l|}{ Table $6-4$} \\
\hline \multicolumn{4}{|l|}{$I$} & 1.15 & \multicolumn{2}{|l|}{ Table 6-1 } \\
\hline \multicolumn{4}{|l|}{ Qh } & $26.025 \mathrm{psf}$ & & \\
\hline \multicolumn{7}{|c|}{ Positive internal pressure } \\
\hline \multicolumn{2}{|c|}{ S. No Location } & Coefficient & \multicolumn{2}{|l|}{ load $=$ qh $*$ Coefficient $*$ spacing } & & Unit \\
\hline 1 & Right wall zone & 0.38 & \multicolumn{2}{|l|}{19.7789696} & & $\mathrm{lb} / \mathrm{ft}$ \\
\hline 2 & Right roof & 0.03 & \multicolumn{2}{|l|}{3.1229952} & & $\mathrm{lb} / \mathrm{ft}$ \\
\hline 3 & Left roof & -0.61 & \multicolumn{2}{|l|}{-63.5009024} & & $\mathrm{lb} / \mathrm{ft}$ \\
\hline 4 & Left wall zone & -0.55 & \multicolumn{2}{|l|}{-28.627456} & & $\mathrm{lb} / \mathrm{ft}$ \\
\hline \multicolumn{7}{|c|}{ Negative internal pressure } \\
\hline S. No & Location & Coefficient & \multicolumn{2}{|l|}{ load $=\mathrm{qh}^{*}$ Coefficient $*$ spacing } & & Unit \\
\hline 1 & Right wall zone & 0.74 & \multicolumn{2}{|l|}{38.5169408} & & $\mathrm{lb} / \mathrm{ft}$ \\
\hline 2 & Right roof & 0.39 & \multicolumn{2}{|l|}{40.5989376} & & $\mathrm{lb} / \mathrm{ft}$ \\
\hline 3 & Left roof & -0.25 & \multicolumn{2}{|l|}{-26.02496} & & $\mathrm{lb} / \mathrm{ft}$ \\
\hline 4 & Left wall zone & -0.19 & \multicolumn{2}{|l|}{-9.8894848} & & $\mathrm{lb} / \mathrm{ft}$ \\
\hline
\end{tabular}

Positive internal moments have more values, hence critical

wind in longitudinal direction is applied by STAAD. Pro

history manually. The modes as shown in Figs. 27, 28, 29, 30,31 and 32 for the mode shapes 1, 2, 3, 4, 5 and 6 of the structure. The analysis of real structures is during nonlinear finite element analysis software.

\section{Design of three storey hospital}

The Fig. 33 and 34 show the variation of shear bending and deflection in members. C-lipped section design properties are shown in Fig. 35. Steel design of members is shown in Fig. 36. Design codes. Different design codes used for the hospital are mentioned in Table 9. 
Table 8 Earthquake load of hospital building

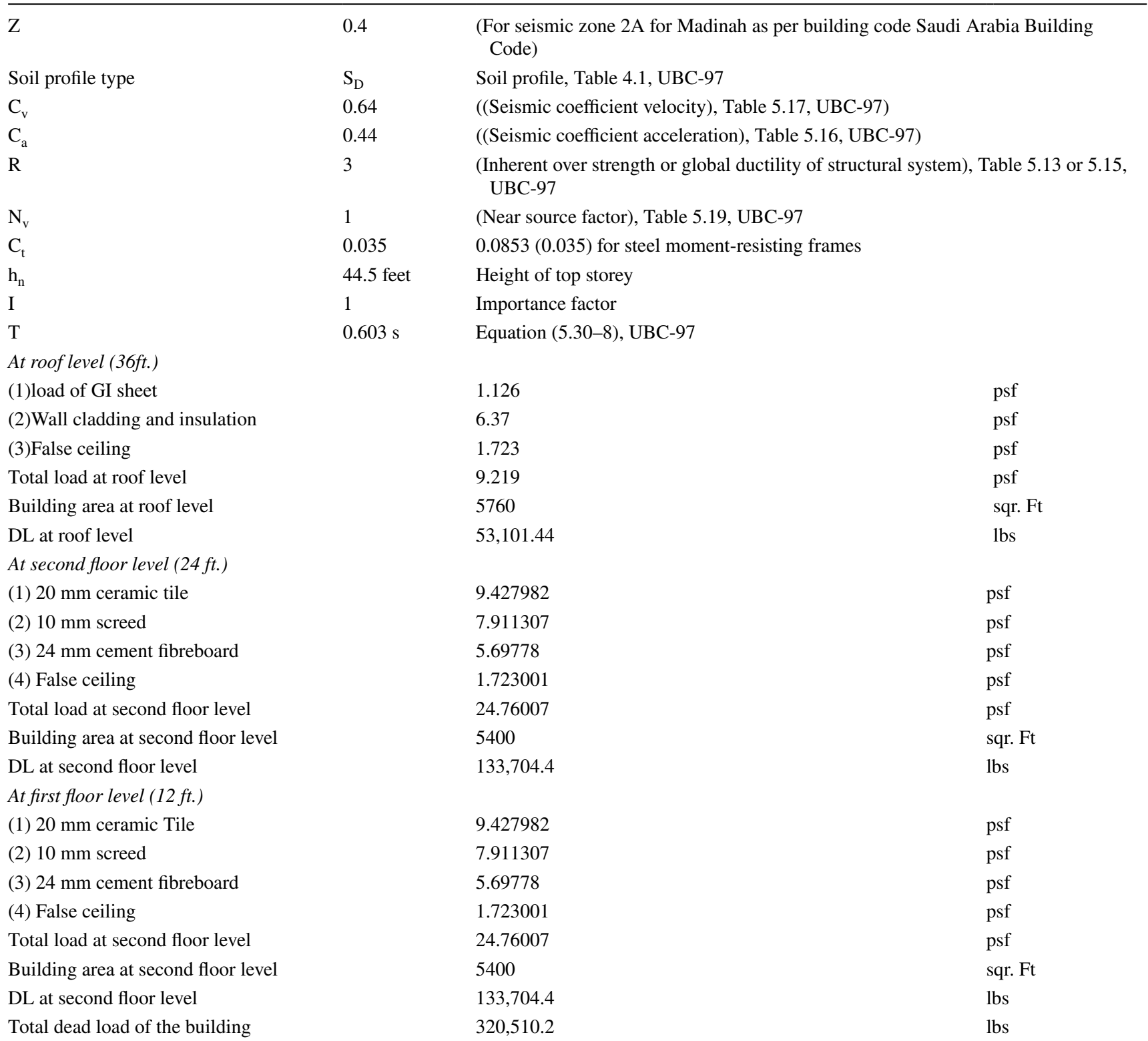

\begin{tabular}{|c|c|c|}
\hline$V$ & $113,387 \mathrm{lbs}$ & Equation (5.30-4), UBC-97 \\
\hline$V_{\min }$ & $15,513 \mathrm{lbs}$ & Equation (5.30-6), UBC-97 \\
\hline$V_{\max }$ & $117,520 \mathrm{lbs}$ & Equation (5.30-5), UBC-97 \\
\hline$F_{\mathrm{t}}$ & $4786 \mathrm{psf}$ & Equation (5.30-14), UBC-97 \\
\hline $\begin{array}{l}\text { Level } \\
\text { (ft) }\end{array}$ & $\begin{array}{l}\text { Total lateral force } \\
\text { (lbs) }\end{array}$ & $\begin{array}{l}\text { Total lateral } \\
\text { force per stud } \\
\text { (lbs) }\end{array}$ \\
\hline 36 & $32,231.344$ & 350.3 \\
\hline 24 & $54,103.63858$ & 588.1 \\
\hline 12 & $27,051.81929$ & 294.1 \\
\hline
\end{tabular}


Fig. 6 Section properties of C-lipped section

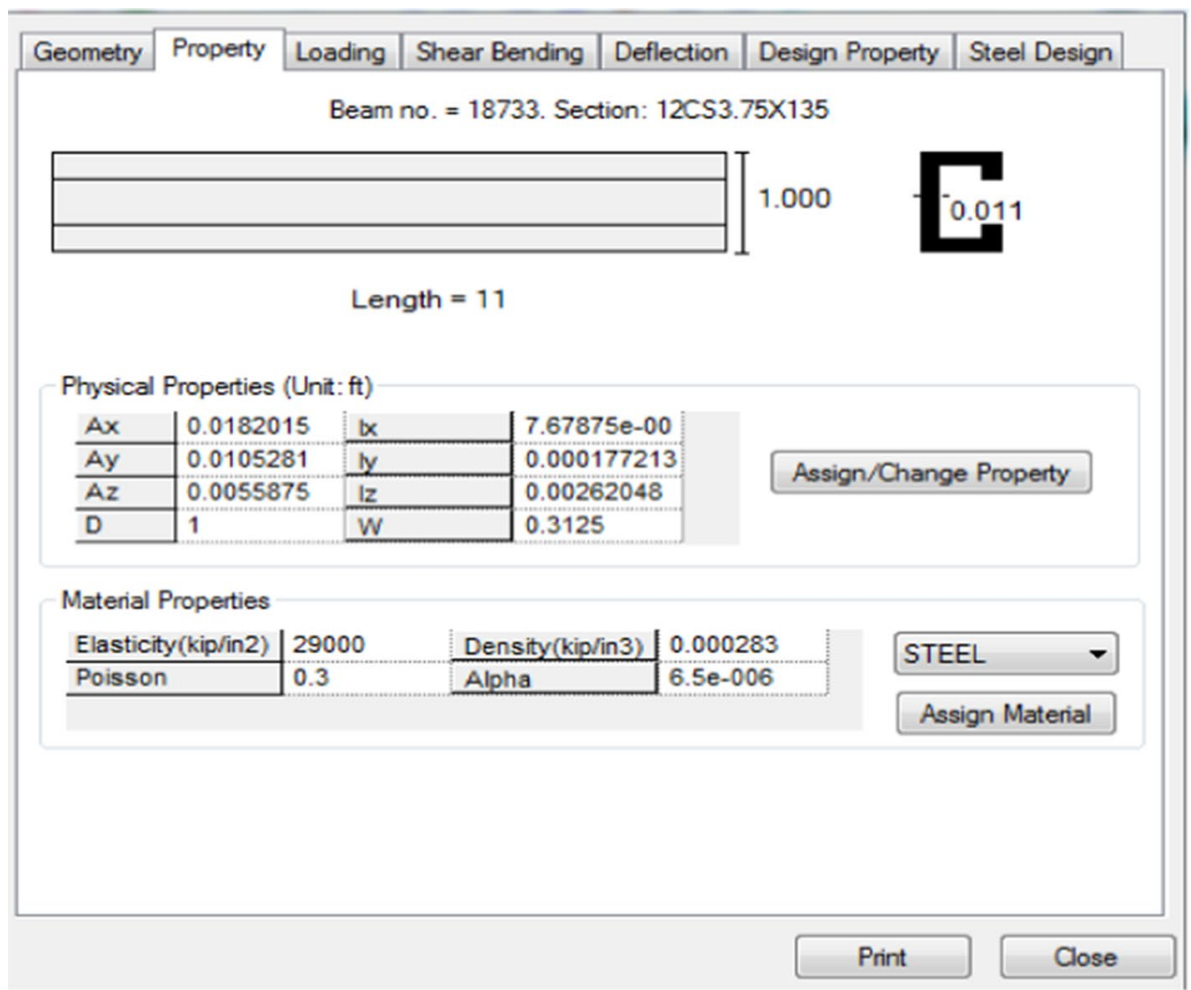

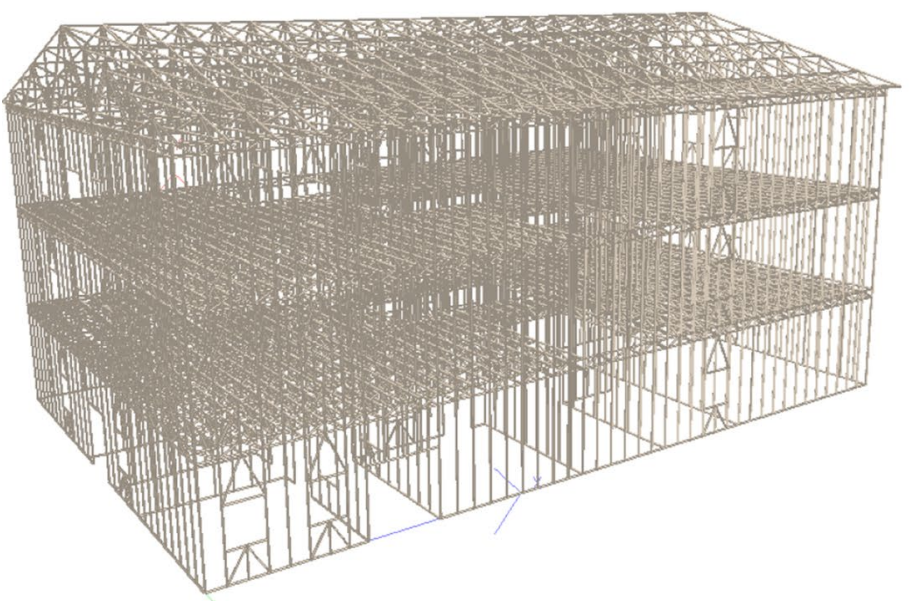

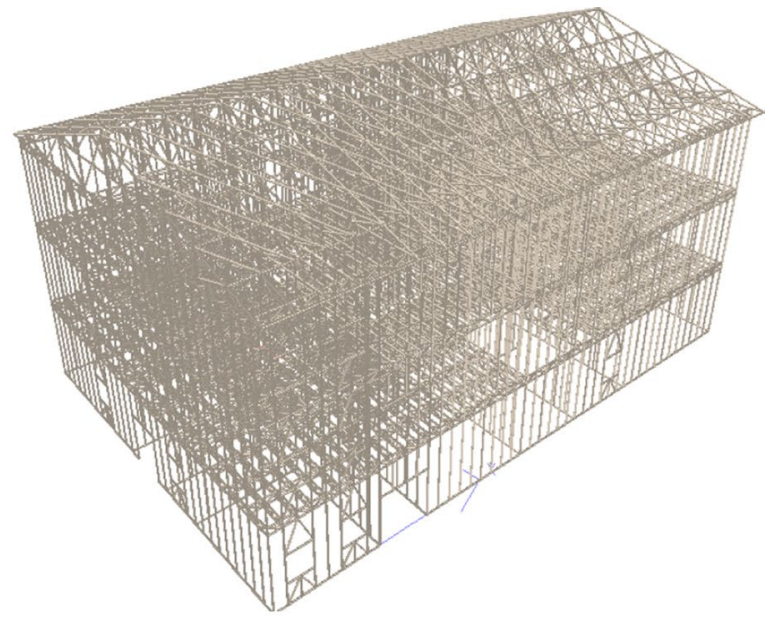

Fig. 7 Isometric view of structural model of hospital

\section{Conclusion}

- This research aimed at introducing the new material for construction in Saudi Arabia, which is structurally stable under various loads (mainly seismic loads). The design results have indicated that cold formed steel is secure under various loads. It can be used for the rehabilitation and reconstruction of disaster affected areas in Saudi 
Fig. 8 Side elevation view of structural model of hospital

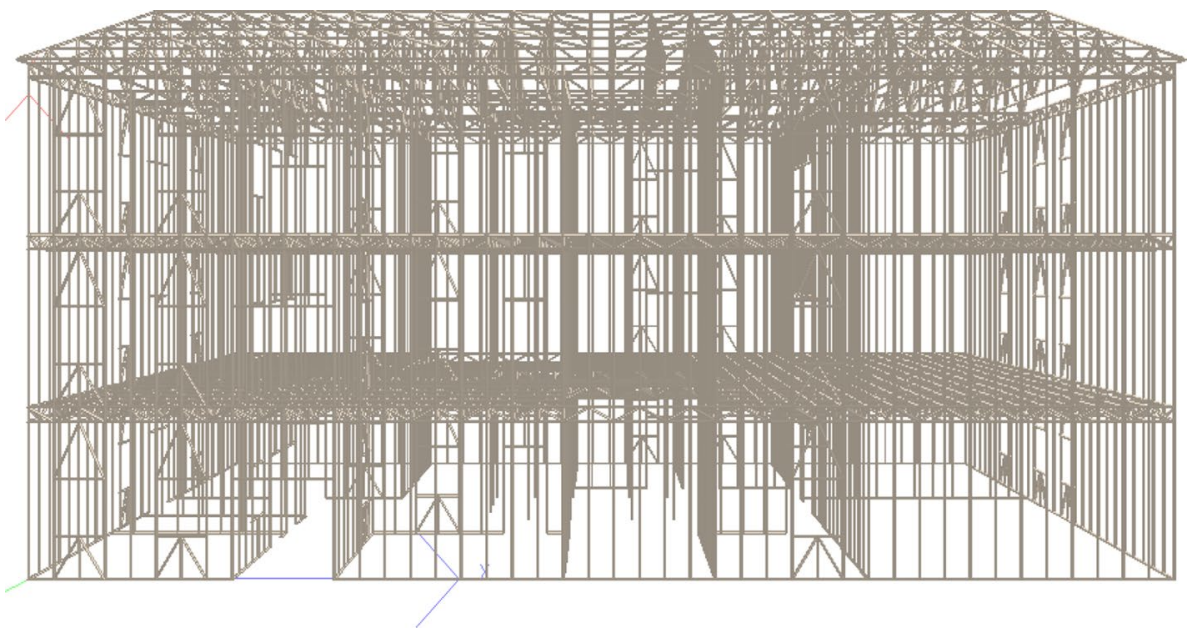

Fig. 9 Front elevation view of structural model of hospital

Fig. 10 Top view of structural model of hospital
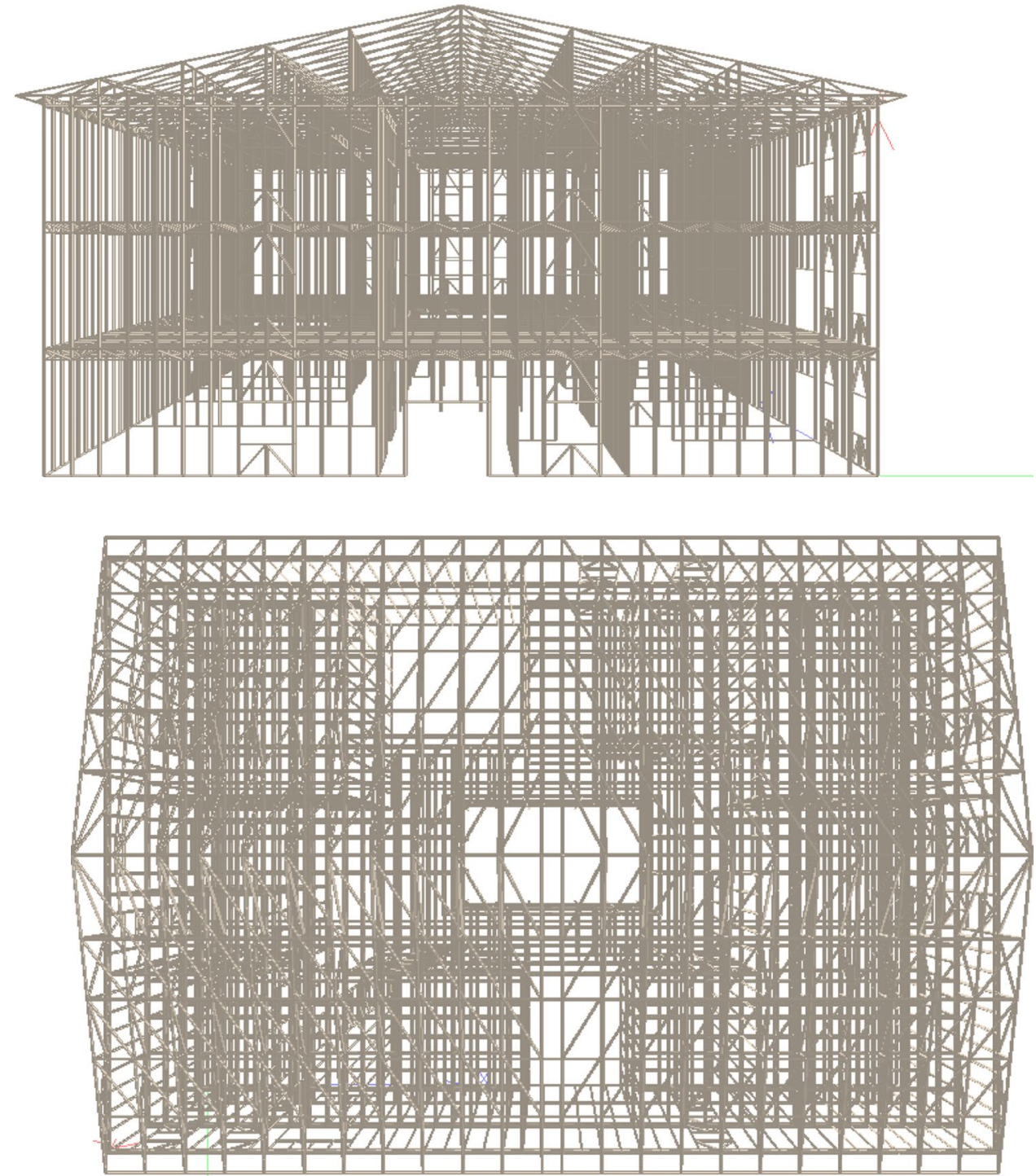


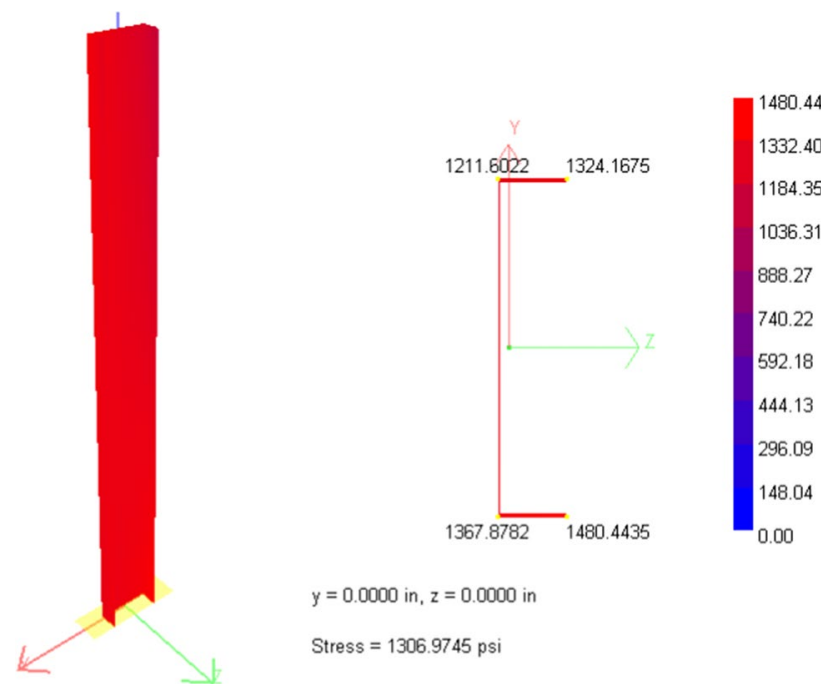

Fig. 11 Stress contours of corner stud of ground floor
Arabia as cold formed steel structures give the most rapid pace of construction.

- The results also indicated that due to lesser self-weight as compared to any other material, it is more earthquake resistant and is least dangerous for human life even if it collapse.

- The results of the design have shown that cold formed steel can be used for the construction of multi-storied buildings. The material performed very well under various load combinations, thus for the construction of mid-rise buildings can be easily used. The material is especially good for the construction of health facilities, which are supposed to be in working condition at fast rapid construction basis even after disaster.

- For all the structures, which have been constructed, the spacing between the studs is kept 2 feet. The results have proven that they can be increased by increasing the depth and/or thickness of the member. The results
Fig. 12 Fx graph of corner stud of ground floor

Fig. 13 Fy of corner stud of ground floor
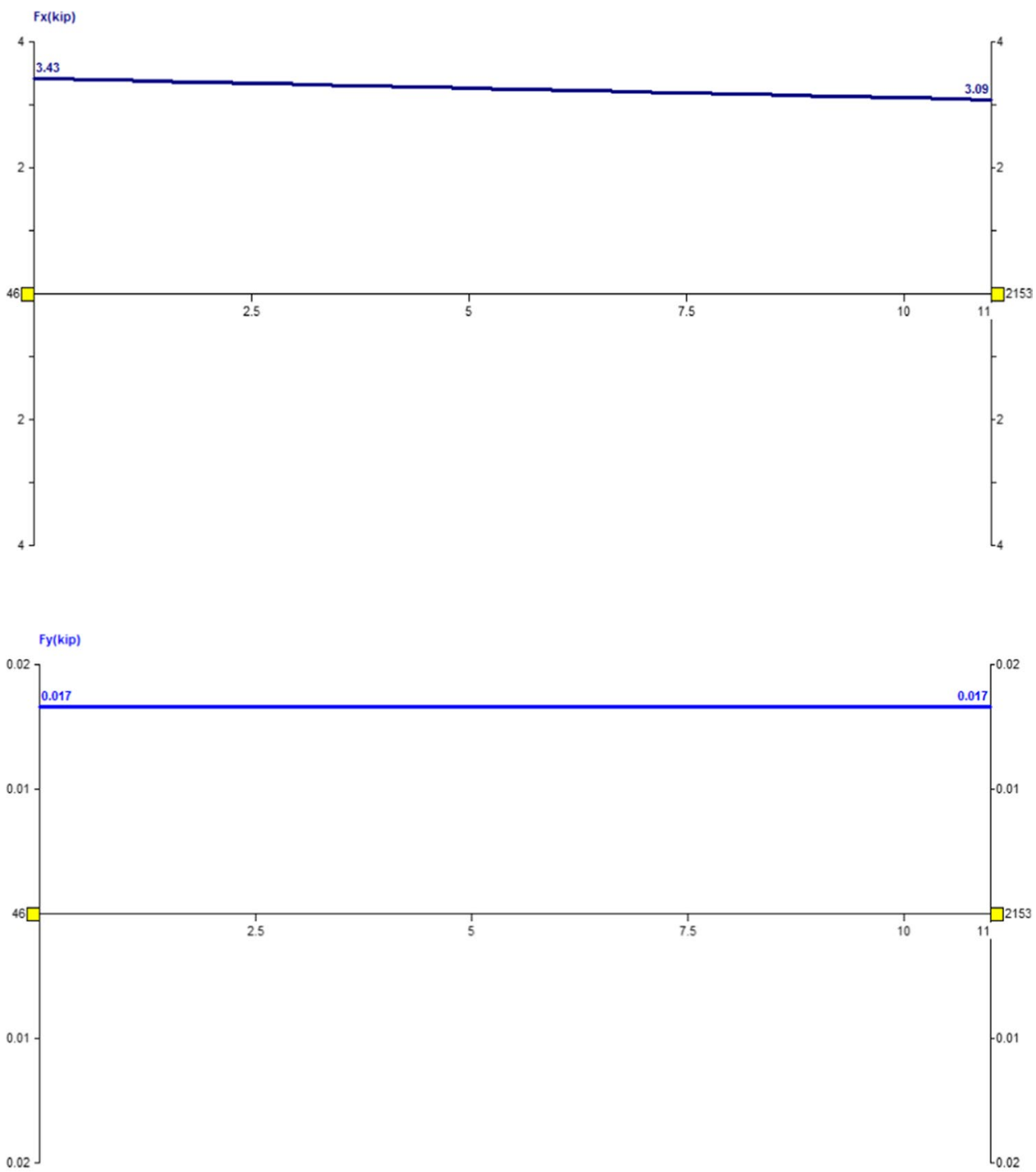
Fig. $14 \mathrm{Mz}$ graph of corner stud of ground floor

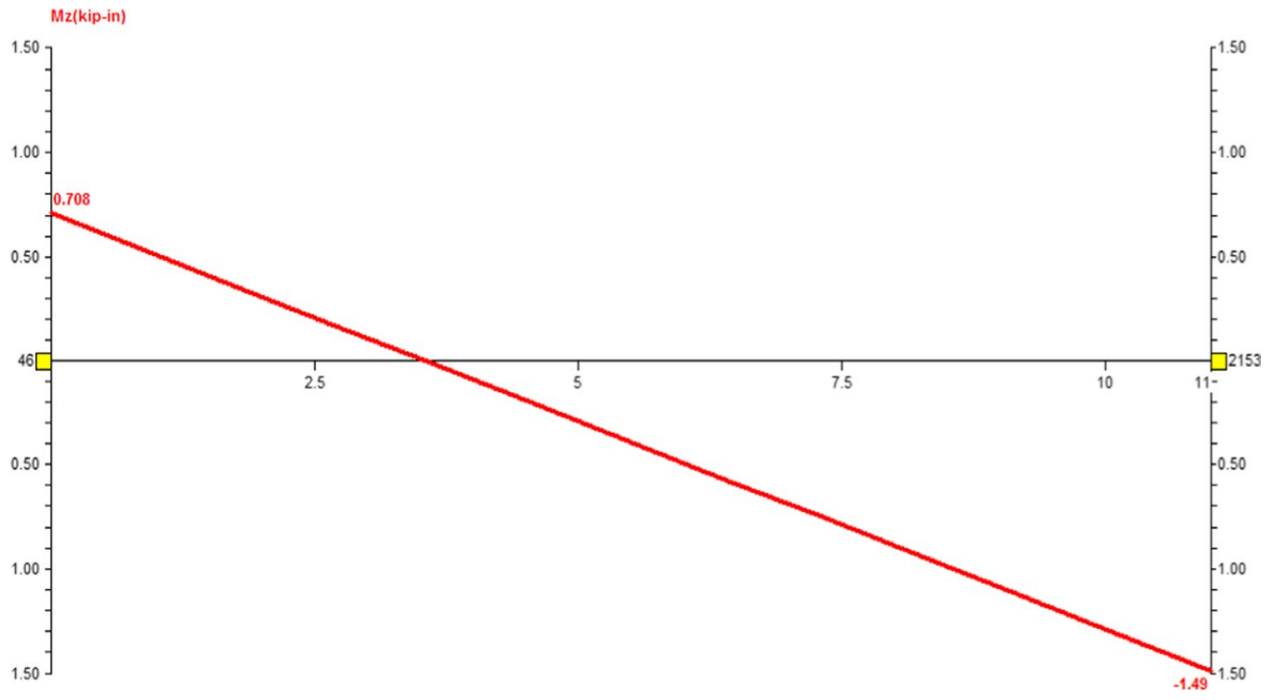

Fig. 15 Stress contours of member of bracing over window
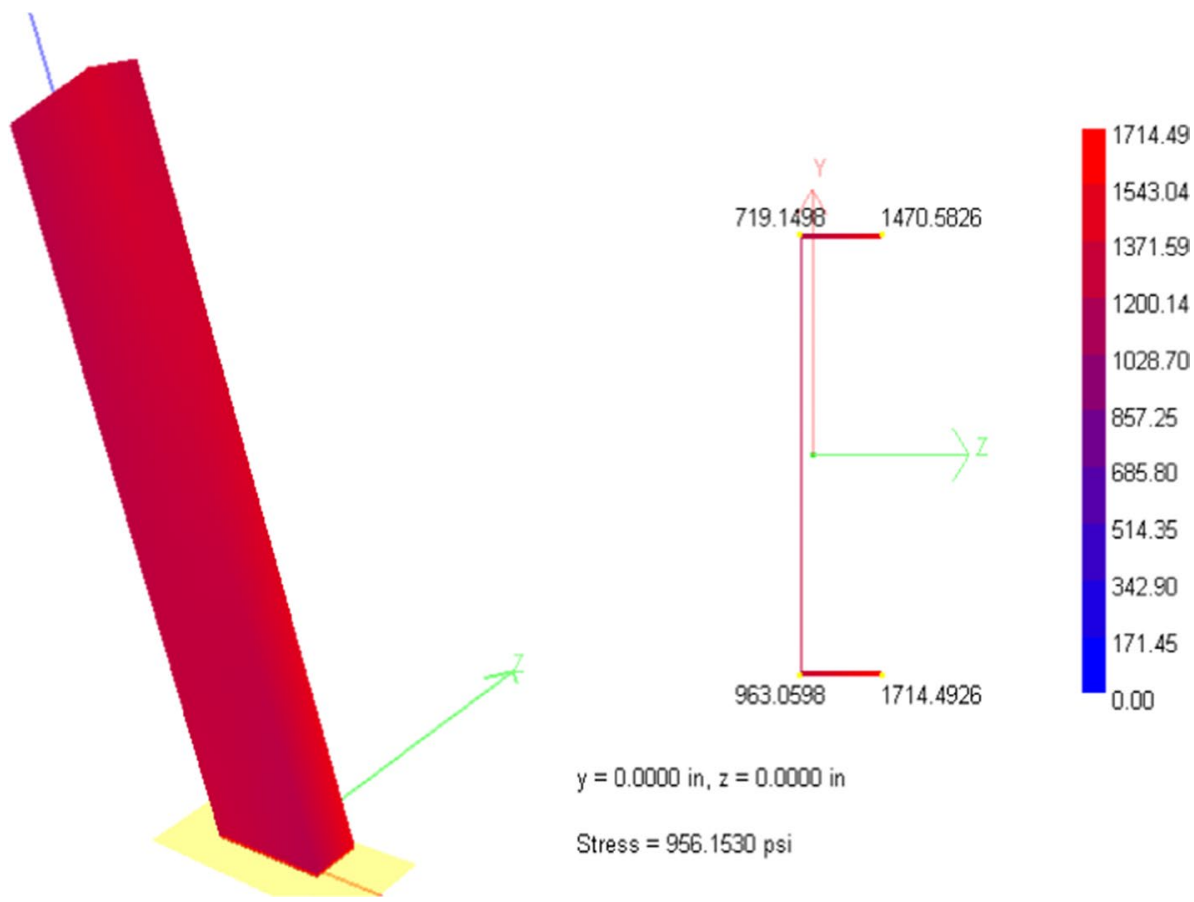

$y=0.0000$ in, $z=0.0000$ in

Stress $=956.1530 \mathrm{psi}$

show that the number of storeys can be enhanced by using greater depth/thickness of members.

- The development authority must also approve material such as cold formed steel for rehabilitation and recon- struction for disaster, pandemic affected areas due to its rapid pace of construction. 
Fig. 16 Fx graph of member of bracing over window

Fig. 17 Fy graph of member of bracing over window

Fig. $18 \mathrm{Mz}$ graph of bracing over window member

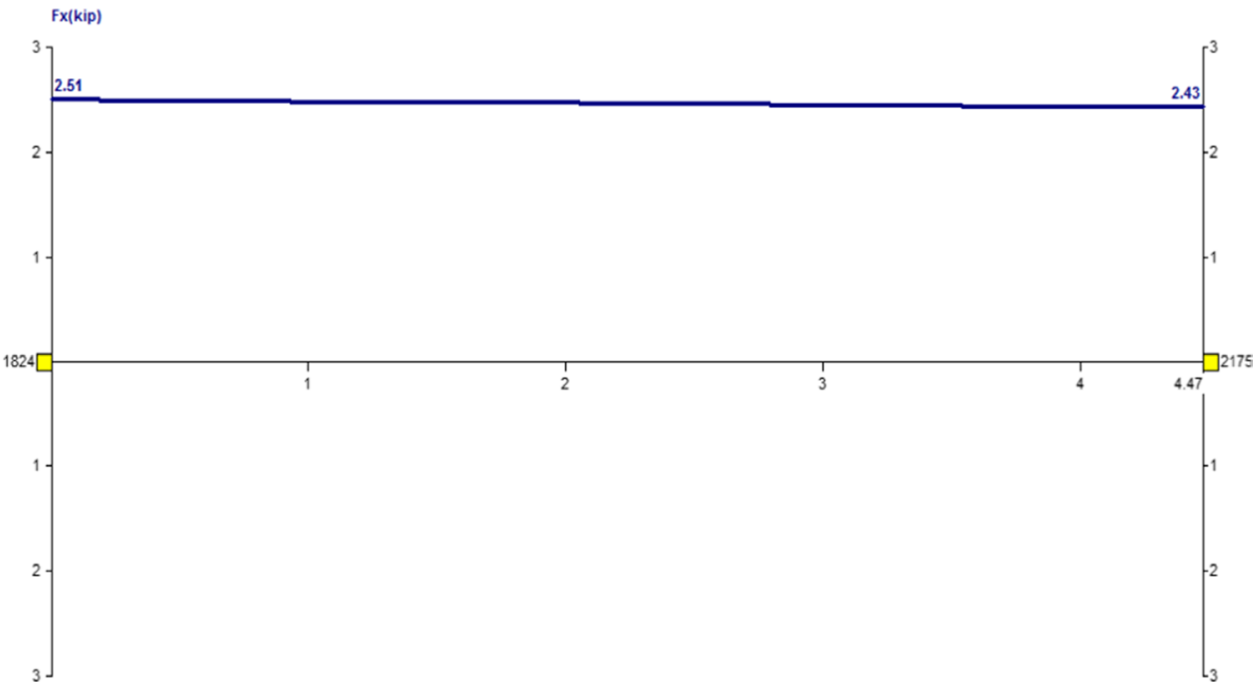

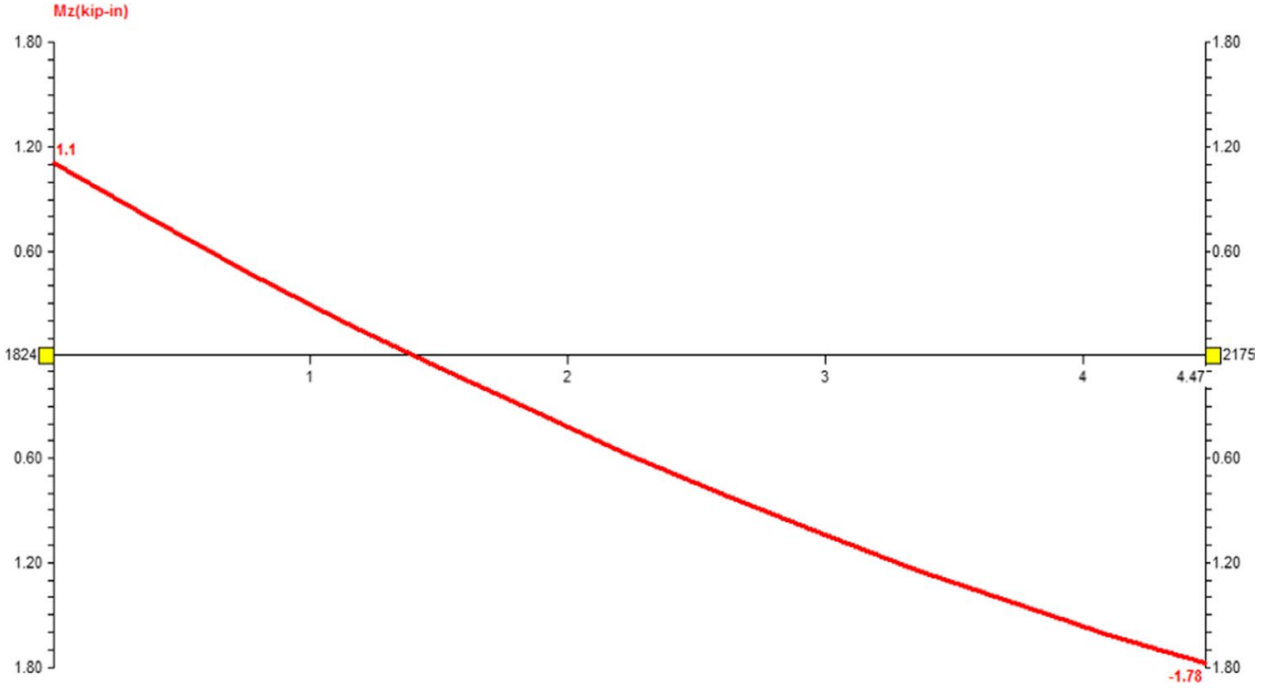




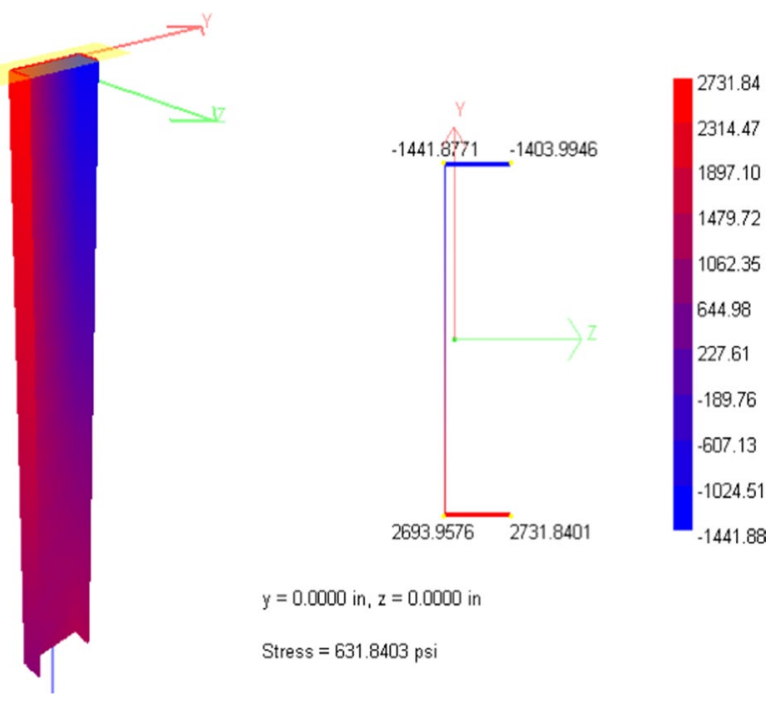

- In conclusion, the cold formed steel is more rapid in construction and earthquake resistant can be the best possible solution for rehabilitation and reconstruction of disaster and pandemic affected areas due to its rapid pace of construction. Moreover, it is favourable for the construction of multi-storey buildings using modern techniques like shear wall. There is a great room for researchers to improve this construction technique.

Fig.19 Stress contours of truss member of bracing over window

Fig. 20 Fx graph of truss member of bracing over window

Fig. 21 Fy graph of truss member of bracing over window

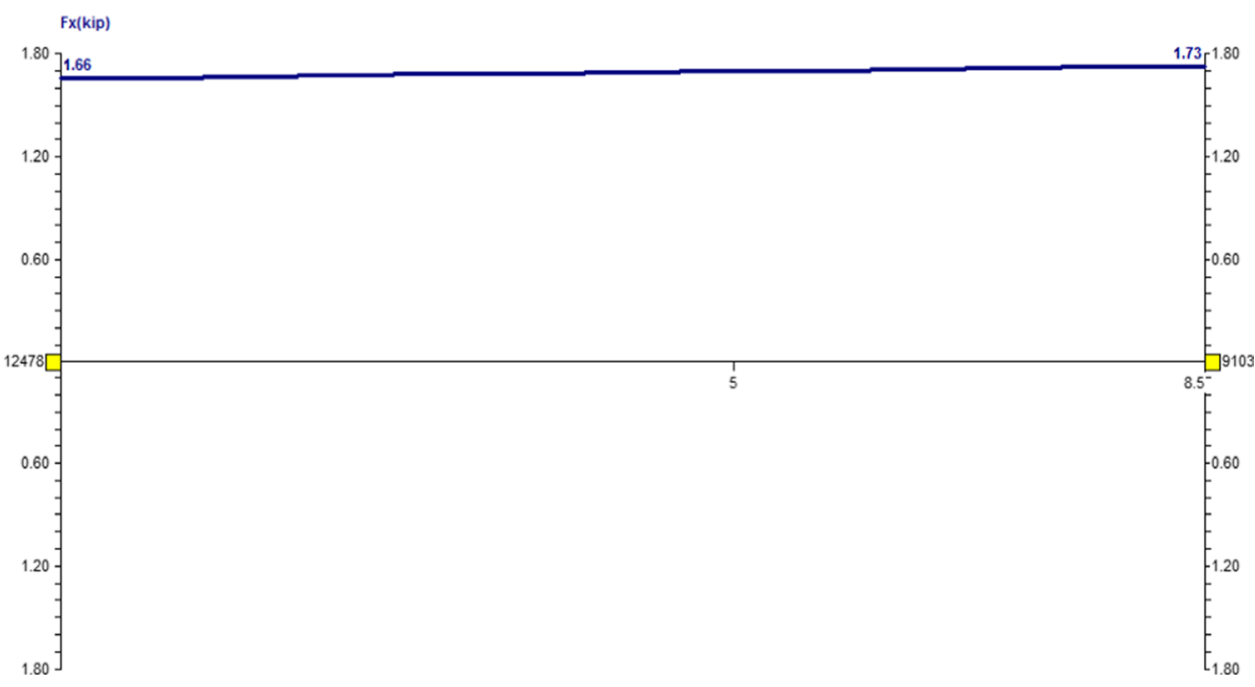


Fig. $22 \mathrm{Mz}$ graph of truss member of bracing over window

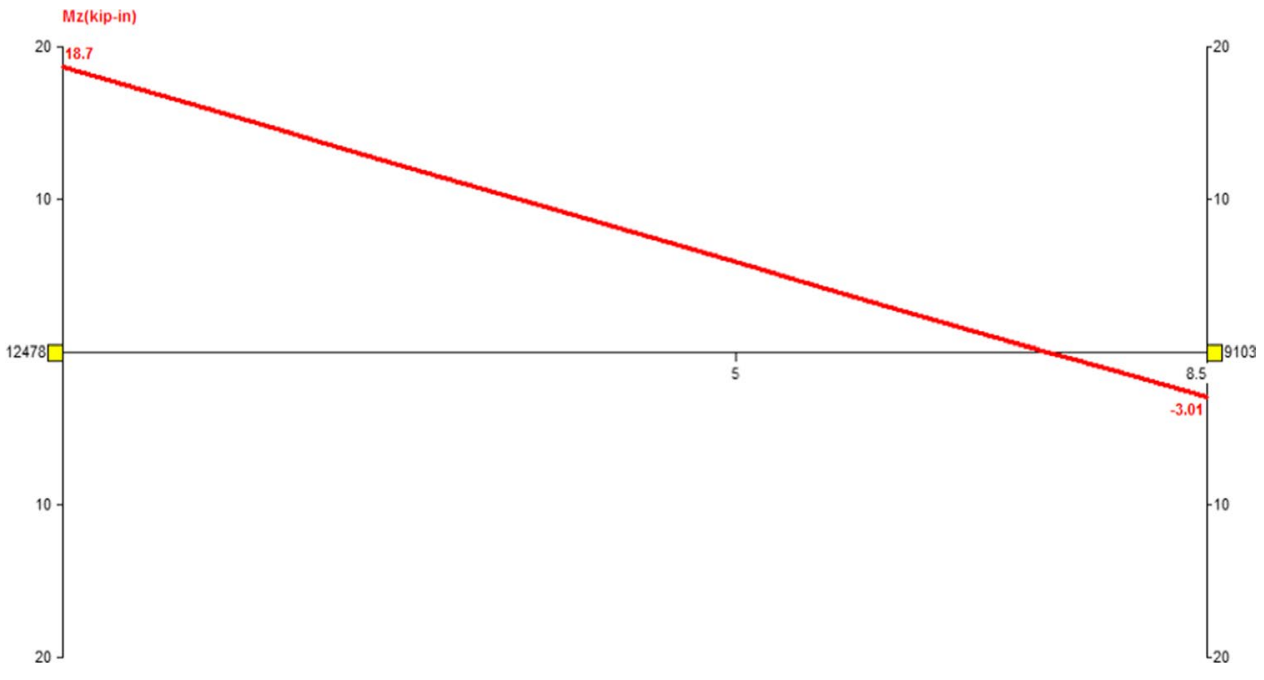

Fig. 23 Stress contours of beam of first floor joist
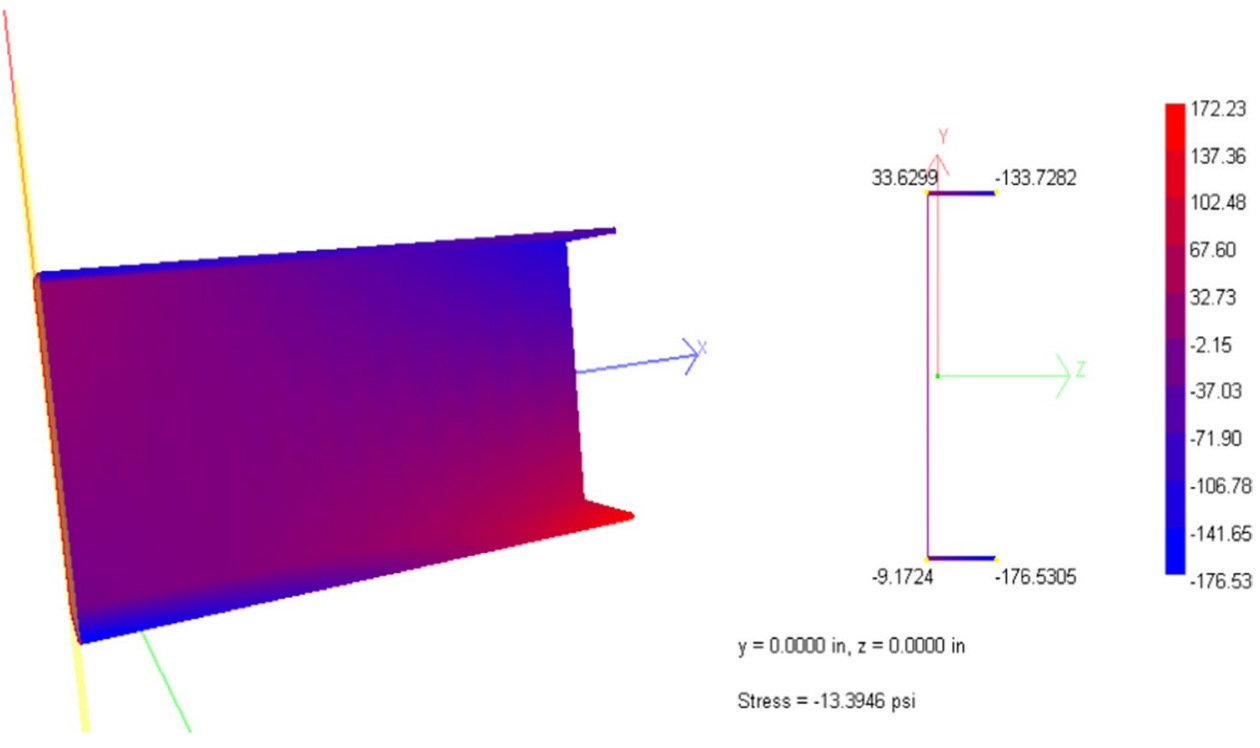

Fig. 24 Fx graph of beam of

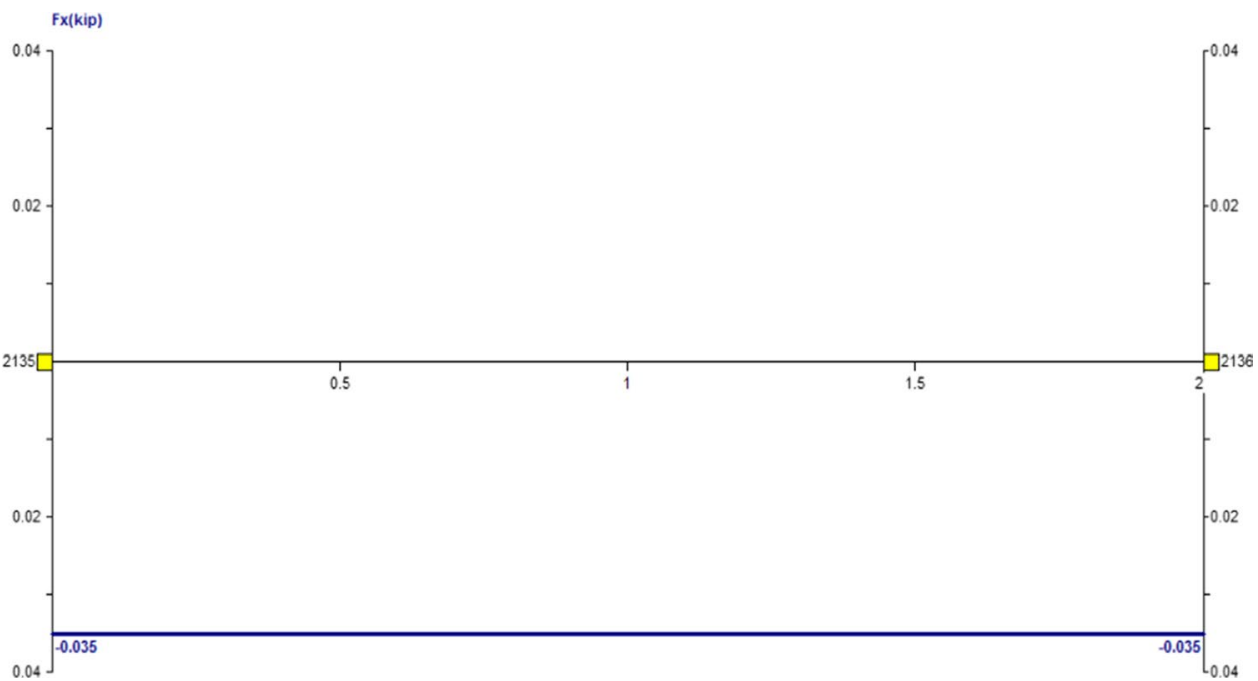


Fig. 25 Fy graph of beam of first floor joist

Fig. $26 \mathrm{Mz}$ graph of beam of first floor joist

Fig. 27 Mode 1 shape of structure frequency: $1.782 \mathrm{~Hz}$. Time period: $0.561 \mathrm{~s}$
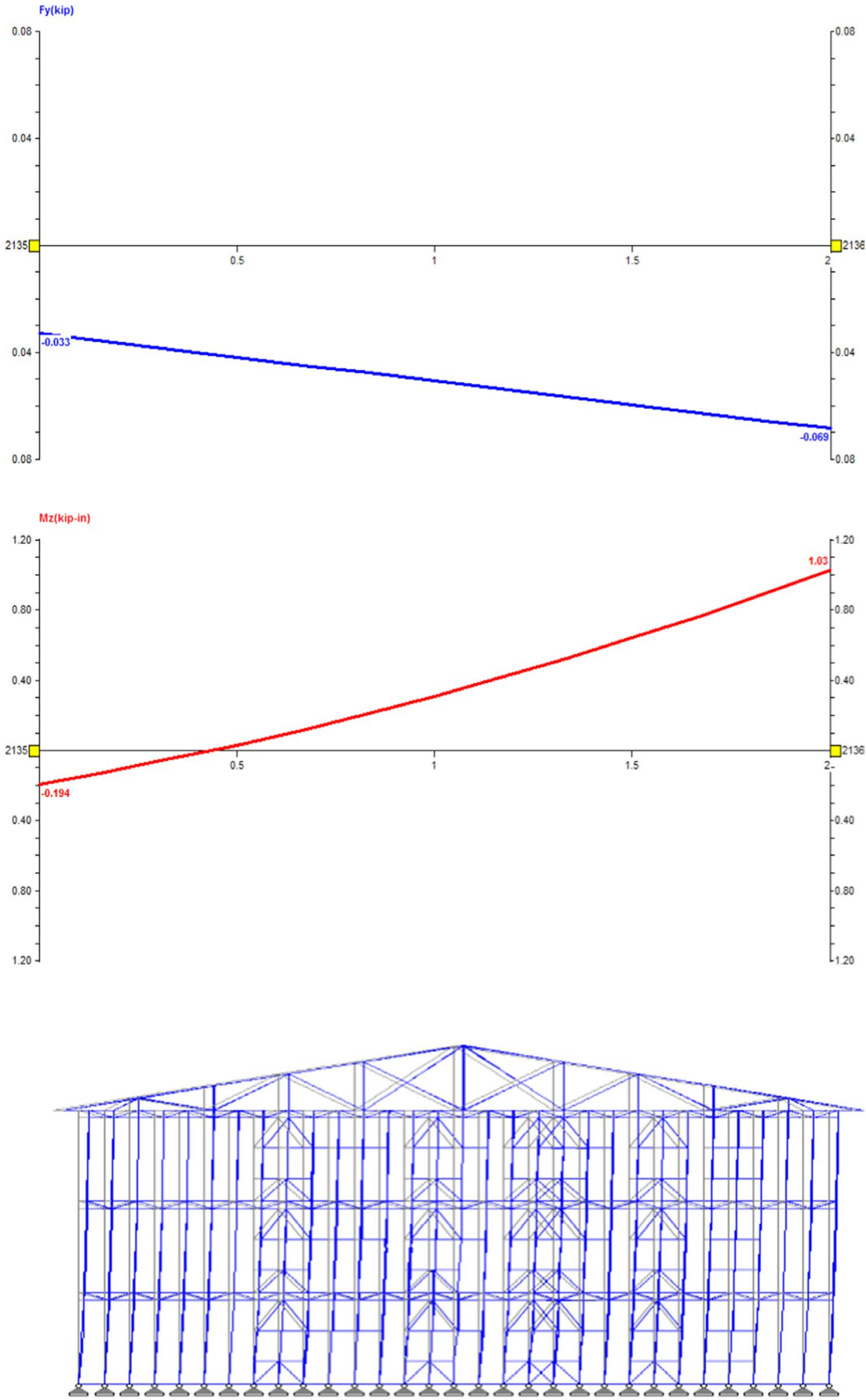
Fig. 28 Mode 2 shape of structure frequency: $3.464 \mathrm{H}$. Time period: $0.289 \mathrm{~s}$

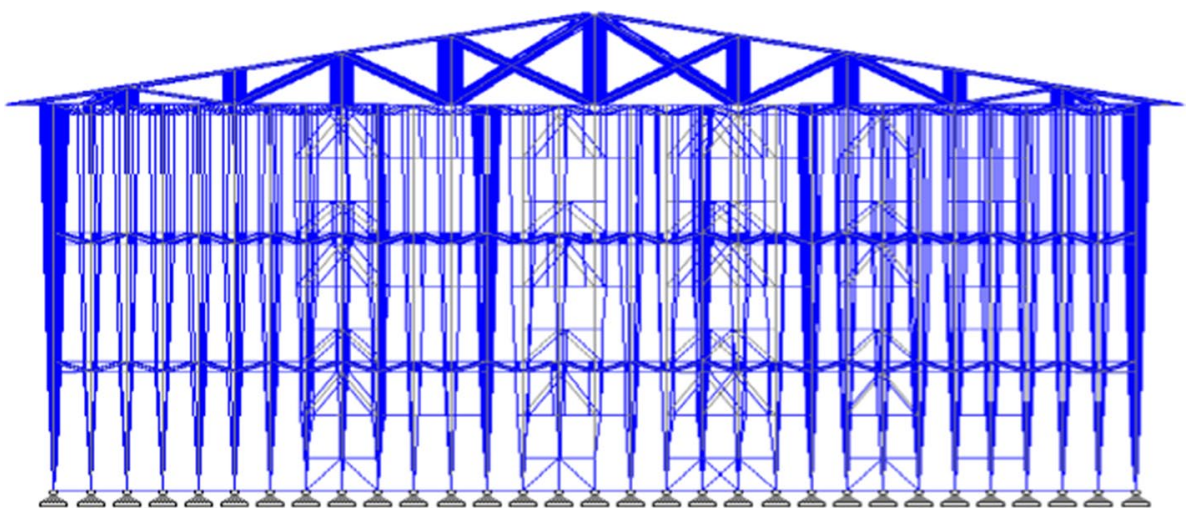

Fig. 29 Mode 3 shape of structure frequency: $4.111 \mathrm{~Hz}$. Time period: $0.243 \mathrm{~s}$

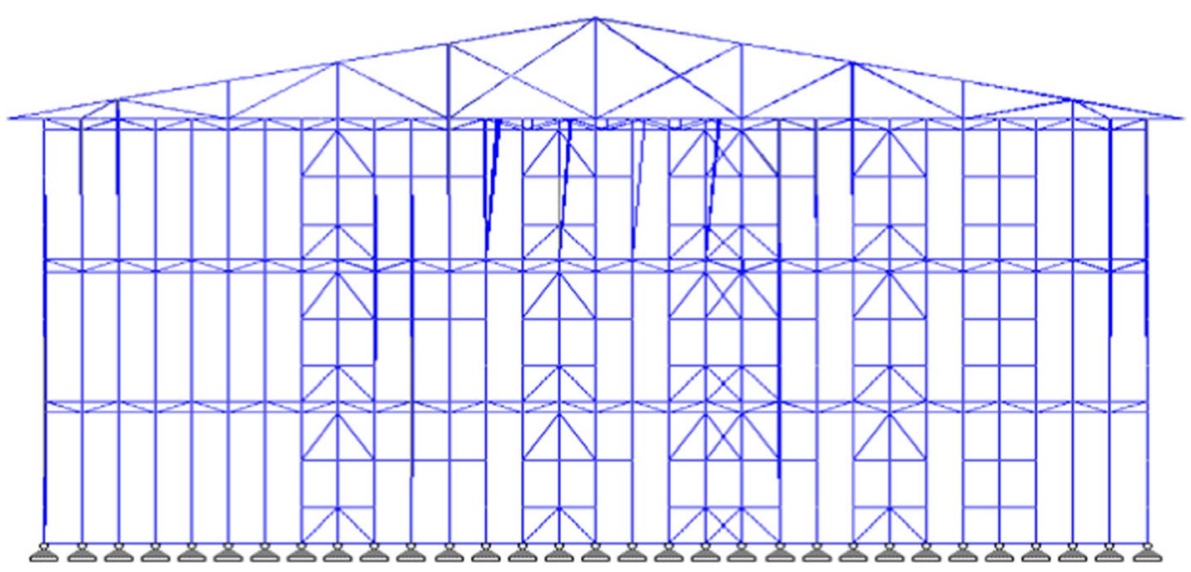

Fig. 30 Mode 4 shape of structure frequency: $4.686 \mathrm{~Hz}$. Time period: $0.213 \mathrm{~s}$

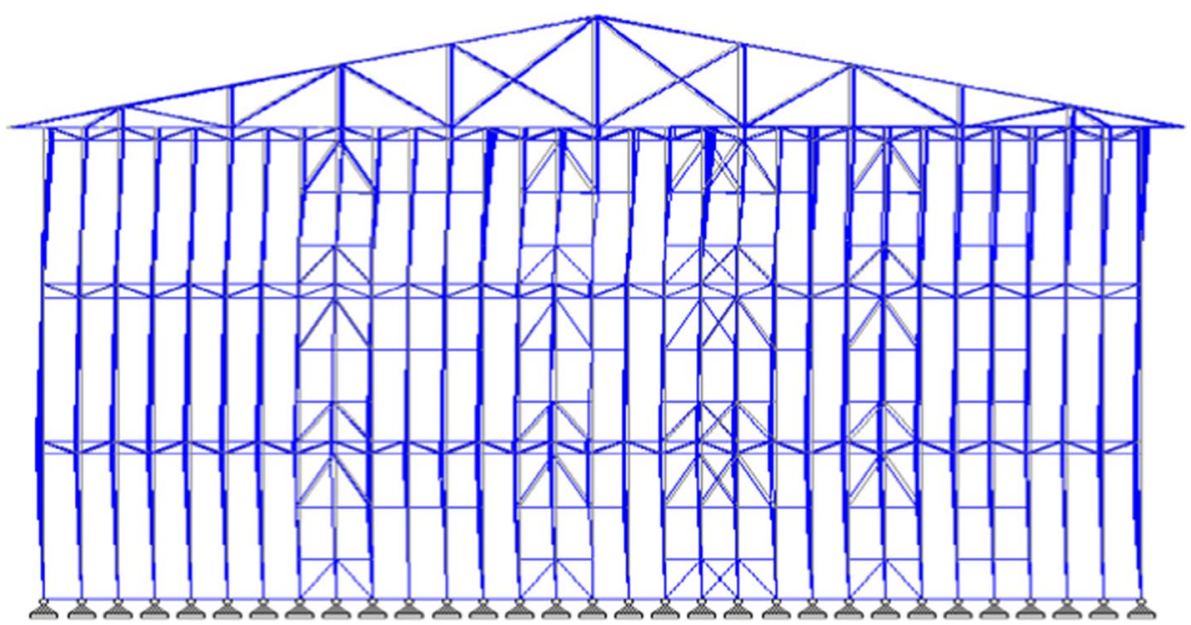


Fig. 31 Mode 5 shape of structure frequency: $5.398 \mathrm{~Hz}$. Time period: $0.185 \mathrm{~s}$

Fig. 32 Mode 6 shape of structure frequency: $6.044 \mathrm{~Hz}$. Time Period: $0.165 \mathrm{~s}$

Fig. 33 Variation of shear bending in members
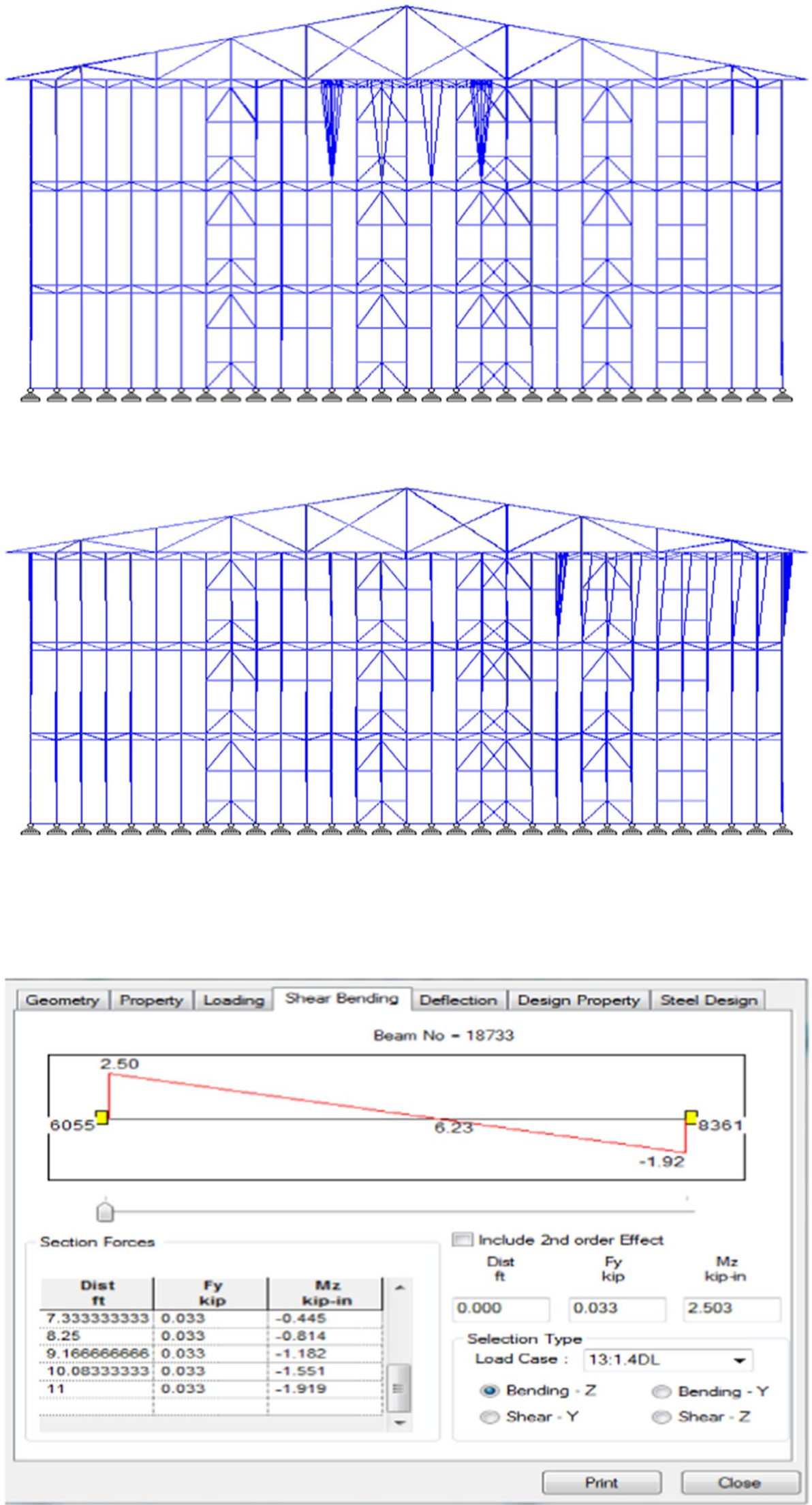
Fig. 34 Deflection in beam member

Fig. 35 Section properties of C-lipped section
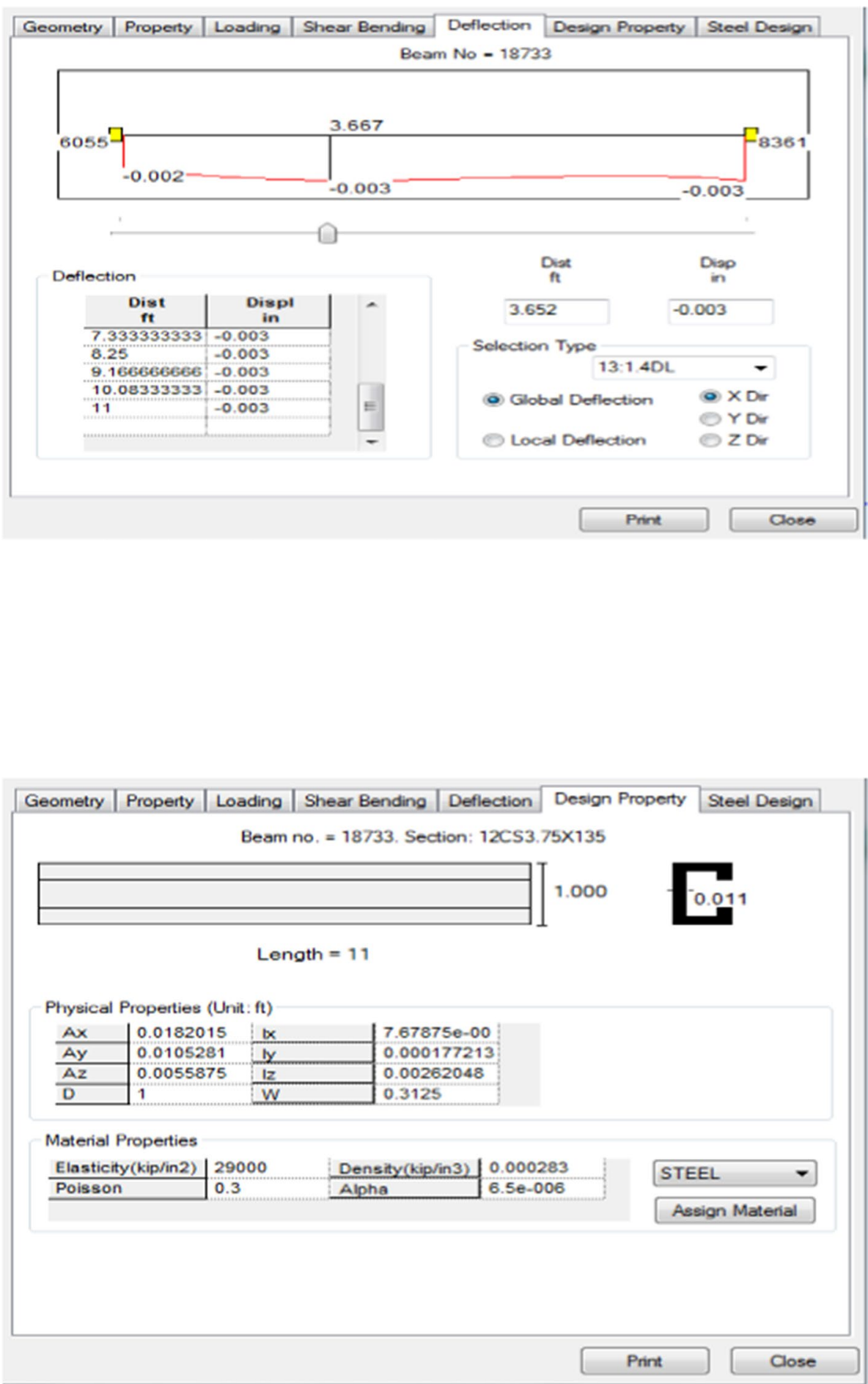
Fig. 36 Steel design of members

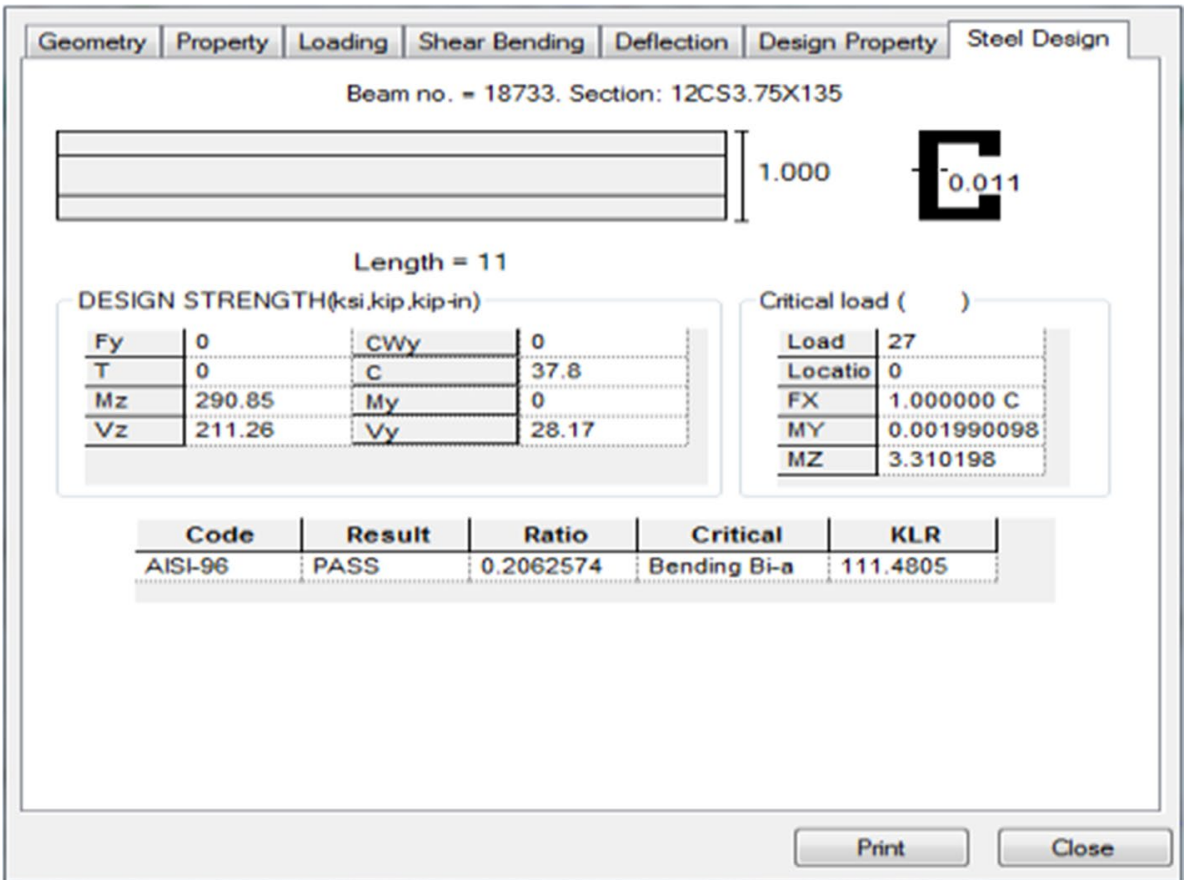

Table 9 Different design codes used for hospital design

\begin{tabular}{ll}
\hline Standards & Description \\
\hline MBMA & $\begin{array}{c}\text { Load combination and wind load } \\
\text { estimation (Sect. 1612.3.2) } \\
\text { Cold formed section design }\end{array}$ \\
AISI & Seismic load calculation \\
UBC-97/PBC & Live load, live roof load, snow load \\
ASCE &
\end{tabular}

Acknowledgements This work was supported by the Deanship of Research Islamic University of Madinah. The authors would like to thank for their support.

\section{Compliance with ethical standards}

Conflict of interest There is not any conflict of interest and ethical issues involved in this research.

\section{References}

1. American Iron and Steel Institute (AISI) (2007) North American specifications for the design of the Cold-Formed Steel Structural Members, 2007 Ed

2. American Iron and Steel Institute (AISI) (2007) Commentary on North American specifications for the design of the cold-formed steel structural members

3. Manual of Steel Construction - ASD-9th Ed. / LRFD 3RD Ed., By American Institute of Steel Construction, Inc. (AISC)

4. Studs, runners (Tracks), and bracing or bridging

5. ASTM C1513 - Standard specification for steel tapping screws for cold-formed steel framing connections
6. American Iron and Steel Institute (2007) North American specification for the design of cold-formed steel structural members. Washington, D.C Published

7. Building code of Saudi Arabia (Seismic Provisions 2007)

8. Ilyas M (2005) E-mail communication with M. Wieland, chairman of the international commission on large dams (icold) committee on seismic aspects of dam design. J Struc Div ASCE, 85(ST9), Cold-Formed, Light Gage Steel Construction, Published 1959

9. Bilham R, Gaur VK, Molnar P (2001) Earthquakes-Himalayan seismic hazard. Science 293:1442-1444

10. T. Parsons, R.S. Yeats, Y. Yagi, A. (2006) Hussain, static stress change from the 8 October, $2005 \mathrm{M}=7.6 \mathrm{Kashmir}$ earthquake. Geophys Res Lett 33

11. Yu, WW, Wolford DS, Johnson AL (1996) Golden anniversary of the AISI specification, proceedings of the 13th international specialty conference on cold-formed steel structures, St. Louis, MO., Published 1996

12. Varum H, Teixeira-Dias F, Marques P, Pinto A, Bhatti AQ (2013) Performance evaluation of retrofitting strategies for non-seismically designed RC buildings using steel braces. Bull Earthq Eng 11(4):1129-1156 (Springer, 1570-761X)

13. Bhatti AQ (2016) Application of Dynamic Analysis and Modeling of Structural Concrete Insulated Panels (SCIP) for Energy Efficient Buildings in Seismic Prone Areas. J Energy Build 128:164-177. https://doi.org/10.1016/j.enbuild.2016.06.049 (ISSN: 0378-7788)

14. Bhatti AQ (2015) Impact response analysis of rock shed under falling weight. J Mater Struct 48(10):3367-3375. https://doi. org/10.1617/s11527-014-0405-5 (ISSN 1359-5997)

15. Bhatti AQ (2016) Scaled accelerographs for design of structures in Quetta, Baluchistan Pakistan. Int J Adv Struct Eng (IJASE) 8(4):401-410

16. Bhatti A. Q., Structural Health Monitoring of single degree of freedom flexible structure having Active Mass Damper under seismic load, Vol 3, Issue 1, 2018, Accepted, Springer Journal of Innovative Infrastructure Solutions ISSN: 2364-4176, 
17. Bhatti AQ, Zamir SZR, Khatoon Z, Ali Q (2011) probabilistic seismic hazard analysis of islamabad. J Asian Earth Sci ISI Index 42(3):468-478

18. Bhatti AQ (2013) Performance of viscoelastic dampers (VED) under various temperatures and application of Magnetorheological dampers (MRD) for seismic control of structures. Mech Time Depend Mater (MTDM) 17(3):275-284 (ISSN: 1385-2000)

19. Saudi Building Code Requirements (2007) 301, 304 Structural loading and forces

20. FEMA (1996) NEHRP guidelines for the seismic rehabilitation of buildings. FEMA 273, Federal Emergency Management Agency

21. Applied Technology Council (1996) Seismic evaluation and retrofit of concrete buildings, Vol. 1. Washington, DC, USA: ATC- 40

22. Mosalam KM, Takhirov SM, Hashemi A (2009) Seismic evaluation of 1940s asymmetric wood - frame building using conventional measurements and high - definition laser scanning. Earthq Eng Struct Dyn 38(10):1175-1197

23. Takhirov S (2010) Laser scanners in structural assessment and finite element modeling. In proceedings of structures congress, ASCE pp. 2226-2237

24. Mosalam KM, Günay S (2013) Hybrid simulations: theory, applications, and future directions. Adv Mater Res 639:67-95

25. Elkhoraibi T, Mosalam KM (2007) Towards error - free hybrid simulation using mixed variables. Earthq Eng Struct Dyn 36(11):1497-1522

26. Sarno LD, Elnashai AS, Nethercot DA (2006) Seismic retrofitting of framed structures with stainless steel. J Constr Steel Res 62(1-2):93-104 